\title{
Early Cretaceous charophytes from south Dobrogea (Romania). Biostratigraphy and palaeobiogeography
}

\author{
Josep Sanjuan a, b, *, Alba Vicente ${ }^{\text {b, c }}$, Jordi Pérez-Cano ${ }^{\text {b }}$, Marius Stoica ${ }^{\mathrm{d}}$, \\ Carles Martín-Closas ${ }^{b}$ \\ a Department of Geology, American University of Beirut-AUB, 11-0236, Beirut, Lebanon \\ b Departament de Dinàmica de la Terra i de l'Oceà, Institut de Recerca de la Biodiversitat-IRBio, Facultat de Ciències de la Terra, Universitat de Barcelona- \\ UB, 08028, Barcelona, Catalonia, Spain \\ ${ }^{c}$ Estación Regional del Noroeste. Instituto de Geología, Universidad Nacional Autónoma de México-UNAM, Blvd. Luis Donaldo Colosio S/N Campus UNISON, \\ 83000 , Hermosillo, Sonora, Mexico \\ ${ }^{\mathrm{d}}$ Department of Geology, Faculty of Geology and Geophysics. University of Bucharest, 010041, Bucharest, Romania
}

\section{A R T I C L E I N F O}

\section{Article history:}

Received 17 July 2020

Received in revised form

5 January 2021

Accepted in revised form 7 January 2021

Available online 21 January 2021

\section{Keywords:}

Charophyta

Taxonomy

Biozonation

Palaeogeography

Mesogea

Early Cretaceous

Tethyan Archipelago

\begin{abstract}
A B S T R A C T
Eleven boreholes and one outcrop of the Lower Cretaceous in South Dobrogea (south-eastern Romania) were sampled for charophytes. Twenty species are described and illustrated in two non-marine rock units, the Zăvoaia Member and the Gherghina Formation. The Zăvoaia Member contains a charophyte assemblage dominated by Feistiella bijuescensis, aff. Mesochara harrisii, Nodosoclavator bradleyi, Clavator bilateralis, and Clavator grovesii var. grovesii, indicating a Berriasian age. Other less abundant species include Feistiella sp., Latochara sp., Mesochara dobrogeica sp. nov., Globator maillardii var. nurrensis, Atopochara trivolvis var. micrandra, Clavator grovesii var. discordis, Hemiclavator adnatus, and Hemiclavator neimongolensis var. posticecaptus. The occurrence of G. maillardii var. nurrensis in this assemblage suggests late Berriasian age. The Gherghina Formation is dominated by the species Atopochara trivolvis var. triquetra and Clavator grovesii var. jiuquanensis. Other less abundant species include Sphaerochara andersonii, aff. Mesochara harrisii, Globator maillardii var. trochiliscoides, Globator maillardii var. biutricularis, Clavator harrisii var. reyi, and Clavator ampullaceus var. latibracteatus var. nov. This assemblage indicates a late Barremian-early Aptian age. This study sheds new light on the palaeobiogeographical distribution of Lower Cretaceous charophytes in the Tethyan realm. Well-known western European charophyte species such as F. bijuescensis, S. andersonii, G. maillardii var. trochiliscoides, H. adnatus, and $H$. neimongolensis var. posticecaptus are herein described for the first time in eastern Europe. Very significantly, this is the first report in Europe of the hitherto North American taxon C. bilateralis, while the species $C$. ampullaceus has previously been reported only from the Middle East and eastern Africa.
\end{abstract}

(c) 2021 Elsevier Ltd. All rights reserved.

\section{Introduction}

Charophyte fructifications (gyrogonites and utricles) have been extensively reported worldwide in non-marine sedimentary rocks as old as Silurian in age (Feist et al., 2005). Fossil charophytes have mainly been used as biostratigraphic markers of non-marine deposits and as palaeoenvironmental proxies of ancient freshwater and brackish-water aquatic systems. Palaeontological works based

\footnotetext{
* Corresponding author. Department of Geology. American University of BeirutAUB, 11-0236, Beirut, Lebanon and Departament de Dinàmica de la Terra i de l'Oceà, Facultat de Ciències de la Terra, Universitat de Barcelona-UB.

E-mail addresses: js76@aub.edu.lb, josepsanjuan@ub.edu (J. Sanjuan).
}

on Cretaceous charophytes are relatively scarce in Romania and in the entire eastern European area. Previous studies based on Cretaceous charophytes from South Dobrogea have been performed by Neagu and Georgescu-Donos (1973), who recovered an assemblage of five species including Atopochara trivolvis var. trivolvis, Clavator grovesii var. jiuquanensis (synonym: Clypeator europaeus), Hemiclavator neimongolensis (reported as Clavator thorali), and Clavator sp. from marly limestone located in a cliff near the village of Peștera (Medgidia, South Dobrogea). These authors provided a relative age of uppermost Barremian-lower Aptian for the studied deposits. Avram et al. (1993) developed a comprehensive biostratigraphic analysis of 20 drilling boreholes in South Dobrogea. These authors provided the relative age of several marine and 
non-marine units, based on foraminifera, ammonites, ostracods, palynomorphs, and charophytes. Furthermore, they dated two rock units, the marine Ramadan Formation and the terrestrial Gherghina Formation, as upper Barremian-lower Aptian and middle-upper Aptian, respectively. Continental and transitional deposits of South Dobrogea were later studied by Stoica (2007), using nonmarine ostracods. This author made a detailed study of 25 hydrogeological boreholes that had been dug more than 50 years ago during the construction of the Danube-Black Sea Canal. Stoica (2007) reported a diverse and well-preserved assemblage composed of forty-seven species of freshwater to brackish-water ostracods, including seven new species. This ostracod assemblage was integrated by Stoica $(1997 ; 2007 ; 2013)$ into the first two ostracod zones of Anderson (1985), defined in the Purbeck and Wealden beds of southern England, i.e., Cypridea dunkeri and Cypridea granulosa zones, or the first two subzones of Theriosynoecum forbesi Zone in the revised zonation performed by Horne (1995). This integration proves the presence of lower Purbeck and the first part of middle Purbeck in the investigated sediments, indicating that the ostracod fauna from the Zăvoaia Member is Berriasian in age. Despite Stoica (2007) having reported the presence of charophytes associated with this Purbeckian ostracod fauna, the charophyte flora has never been studied in detail.

In the neighbouring Pre-Dobrogean Basin (south-western Ukraine and easternmost Moldova), charophytes were studied by Shaikin (1976) from several oil and gas drilling boreholes. This author identified thirty species and defined four biostratigraphic zones in deposits ranging in age from Middle Jurassic to Lower Cretaceous (Barremian). However, neither proper illustrations nor detailed descriptions were provided by this author. Shaikin et al. (1992) attempted to establish a charophyte correlation between the Pre-Dobrogean Basin, the Crimean plain (Ukraine) and the North Caspian depression (Russia and Kazakhstan), on the basis of private data compiled by oil companies. They highlighted the potential of charophytes in biostratigraphic correlations between distant basins. However, in the last three decades, no significant studies based on Mesozoic charophytes have been published concerning the South Dobrogea and Pre-Dobrogean basins.

The present study illustrates and describes in detail the Lower Cretaceous charophyte flora from South Dobrogea (south-eastern Romania), providing the relative age of the two lithological units, the Zăvoaia Member (upper part of the Amara Formation) and the Gherghina Formation. These results are compared with those obtained by the study of ostracods from the same boreholes. Moreover, this study analyses the palaeobiogeographic distribution of this flora since several species are reported for the first time in the eastern part of the Tethyan Cretaceous Archipelago.

\section{Materials and methods}

Fossil charophytes were extracted from 45 soft rock samples, initially prepared for ostracods (marly limestone and clays), from 11 drilling cores and one outcrop, in seven localities of South Dobrogea, i.e., Dunărea, Poarta Albă, Saligny, Nazarcea, Ilie Barza, Cernavodă and Fetesti Baltă (Fig. 1). About 300 g of sediment per sample were extracted from the drilling cores. About $2 \mathrm{~kg}$ of sediment was recovered from the single outcrop sample in Cernavodă. Sediments were disaggregated and sieved using sieves with mesh apertures ranging from $0.063 \mathrm{~mm}$ to $0.125 \mathrm{~mm}$. Microfossils were then picked out by hand using a light microscope Zeiss Stemi SV 11 housed at the Geology Department of the University of Bucharest (Romania). Selected fossil charophytes were cleaned with an ultrasound machine and measured using the Motic Images Plus 2.0 software with a Motic BA310 stereomicroscope housed at the Department of Earth and Ocean Dynamics of the University of
Barcelona, Spain (Departament de Dinàmica de la Terra i de l'Oceà, Facultat de Ciències de la Terra, Universitat de Barcelona). Finally, representative specimens were photographed using a Quanta 200 scanning electronic microscope (SEM) housed in the Scientific and Technological Centres of the University of Barcelona, Spain (CCiTUB). The material studied and illustrated herein, and the holotypes/ para-types extracted from South Dobrogea are housed in the Laboratory of Palaeontology of the University of Bucharest (LPB). The collection enumeration ranges from LPB_IV_CH 101 to LPB_IV_CH 172.

\section{Geological and stratigraphic setting}

The region of South Dobrogea represents an elevated sector of the Moesian Platform that lies in south-eastern Romania between the lower course of the Danube and the Black Sea coast. The Moesian Platform is a Precambrian block incorporated in the epiHercynian European Platforms (Săndulescu, 1984). The Dobrogean sector of the Moesian Platform is divided by the Capidava-Ovidiu Fault into two tectonic compartments, Central Dobrogea and South Dobrogea (Fig. 1).

The South Dobrogea basement has been identified in a few boreholes located near Palazu and Cocosu, below the depth of $500 \mathrm{~m}$ (Visarion et al., 1988; Ionesi, 1994). The basement consists of Archaic gneisses (Ovidiu series), Lower Proterozoic high-grade metamorphic rocks (Palazu series) and Upper Proterozoic (Vendian) volcano-sedimentary rocks (Cocosu Formation). Several relative ages were inferred from the covering sedimentary sequences in South Dobrogea, i.e., Cambrian?-Carboniferous, Permian?-Triassic, Middle Jurassic-Upper Cretaceous, EoceneOligocene, and Miocene-Pliocene. These sedimentary cycles are separated by stratigraphic gaps of different time spans (Băncilă, 1973; Tătărîm et al., 1977; Avram et al., 1988, 1993; Dragastan et al., 1998). The spatial distribution of these sedimentary sequences is not uniform in South Dobrogea and they are influenced by the regional palaeogeography and tectonics.

Several Upper Jurassic-Lower Cretaceous lithostratigraphic units have been defined in South Dobrogea (Cernavodă area), based on surface and subsurface data obtained over decades of intense research (Fig. 2). The oldest deposits intercepted in boreholes are represented by the Rasova Formation which is composed of a 600m-thick carbonate sequence (limestone and dolomite), Oxfordian-Tithonian in age (Dragastan, 1985; Dragastan et al., 1998). The Rasova Formation is covered by a thick marine and continental sequence termed the Amara Formation (Dragastan, 1985). This unit is divided into two members with different lithologies, namely Cireşu and Zăvoaia. The Cireşu Member consists of intervals of evaporites (gypsum, anhydrite, and gypsiferous clays) that are up to 200-m-thick. This lithological unit was first recognised by Băncilă (1973) and displays a wide extension in South Dobrogea and in the eastern Romanian Plain. The Cireşu Member represents the base of the Purbeckian facies and is late Tithonian in age. The Zăvoaia Member is divided into two characteristic Lower Cretaceous intervals. The first interval is composed of a 60-m-thick carbonate succession (bioclastic limestones, marlstones, and oolites), rich in early Berriasian marine macro- and microfauna, representing a marine intercalation within the Purbeckian Amara Formation (Stoica, 2007). This carbonate sequence is overlaid by another 60-m-thick sequence of variegated clays, marls, marly limestones, calcarenites, calcareous sandstones, oolitic limestones, and clayey sandstones. This unit has previously been reported by Băncilă (1973) as the "poly-coloured clay complex". Dragastan (1985) included it in the Zăvoaia Member of the Amara Formation. The ostracod fauna extracted from the Zăvoaia Member allowed correlation with the Purbeckian ostracod zonation of 


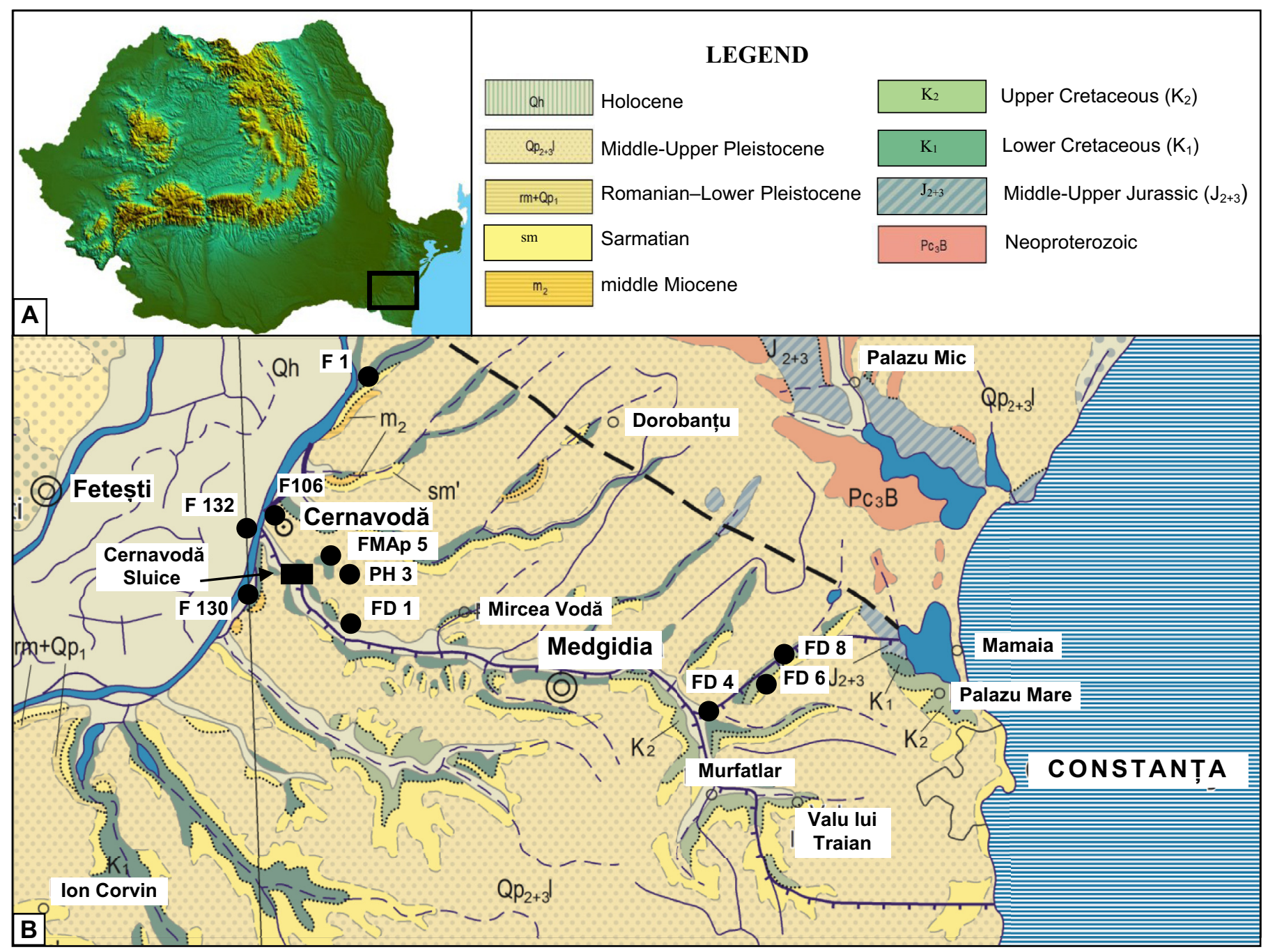

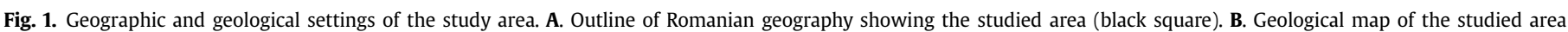
showing the location of the 11 drilled boreholes and the outcrop sampled (modified from Dragastan et al., 2014).

Horne (1995). Stoica (2007) identified the two lower ostracod zones, Cypridea dunkeri and Cypridea granulosa, suggesting that the upper part of the Zăvoaia Member is Berriasian in age. Rocks attributed to the Zăvoaia Member are not exposed in South Dobrogea, but are located close to the surface, being encountered in wells as deep as 50-m to 90-m. The Zăvoaia Member was occasionally intercepted during excavation works to build the foundations of the new railway bridge over the Danube and the DanubeBlack Sea Canal. Most of the charophyte species described in this study have been extracted from marls and clays located at the 2nd interval of the Zăvoaia Member (Fig. 2). This charophyte-rich member is covered by a 40 -m-thick carbonate marine sequence termed the Cernavodă Formation which includes the Hinog and Alimanu members. This formation crops out in several locations in South Dobrogea and it has been studied in detail on the right bank of the Danube River, upstream of the Cernavodă bridge. The diverse and rich fossil content extracted from this marine unit (shallow marine macro- and microfauna) indicates a late Berriasian-Valanginian age (Neagu et al., 1977; Neagu and Dragastan, 1984; Avram et al., 1995; Neagu et al., 1997; Dragastan et al., 1998, 2014). The Cernavodă Formation is discordantly overlaid by the BarremianAptian fluvio-lacustrine deposits of the Gherghina Formation. Fluvial facies are composed of fine to medium clast-supported conglomerate beds with reddish clay matrix alternated with whitish sandstone and kaolinitic claystone intervals. Lacustrine deposits are represented by yellow claystone beds, up to $0.5-\mathrm{m}$ thick, that are rich in Wealdian microfossils (freshwater ostracods and charophyte fructifications). Part of the charophyte species described here was recovered from this lacustrine interval of the Gherghina Formation. The fluvio-lacustrine facies of the Gherghina Formation changes vertically and laterally towards the marine marlstones and fine sandstones of the Ramadan Formation (Fig. 2). This rock unit provided abundant marine fauna such as ostreid bivalves, ostracods and foraminifera (mainly orbitolinids).

The studied charophyte assemblage was extracted from several hydrogeological/hydrotechnical cores along the Carasu Valley (F1 Dunărea, F132 Cernavodă Pod, FD1 Saligny, FD Poarta Albă, FD6, and 8 Nazarcea) that were dug between the years 1958 and 1968 in South Dobrogea (Fig. 1). Most of these cores were first described by Bănciă (1973). They are up to 300-m-deep, intercepting several lithological units, as previously mentioned, i.e., Upper Jurassic limestones and dolomites of the Rasova Formation, uppermost Jurassic evaporites of the Cireşu Member, Berriasian marine and Purbeckian sediments of the Zăvoaia Member, upper BerriasianValanginian marine carbonates of the Cernavodă Formation, and Barremian/Aptian continental and marine deposits of the 


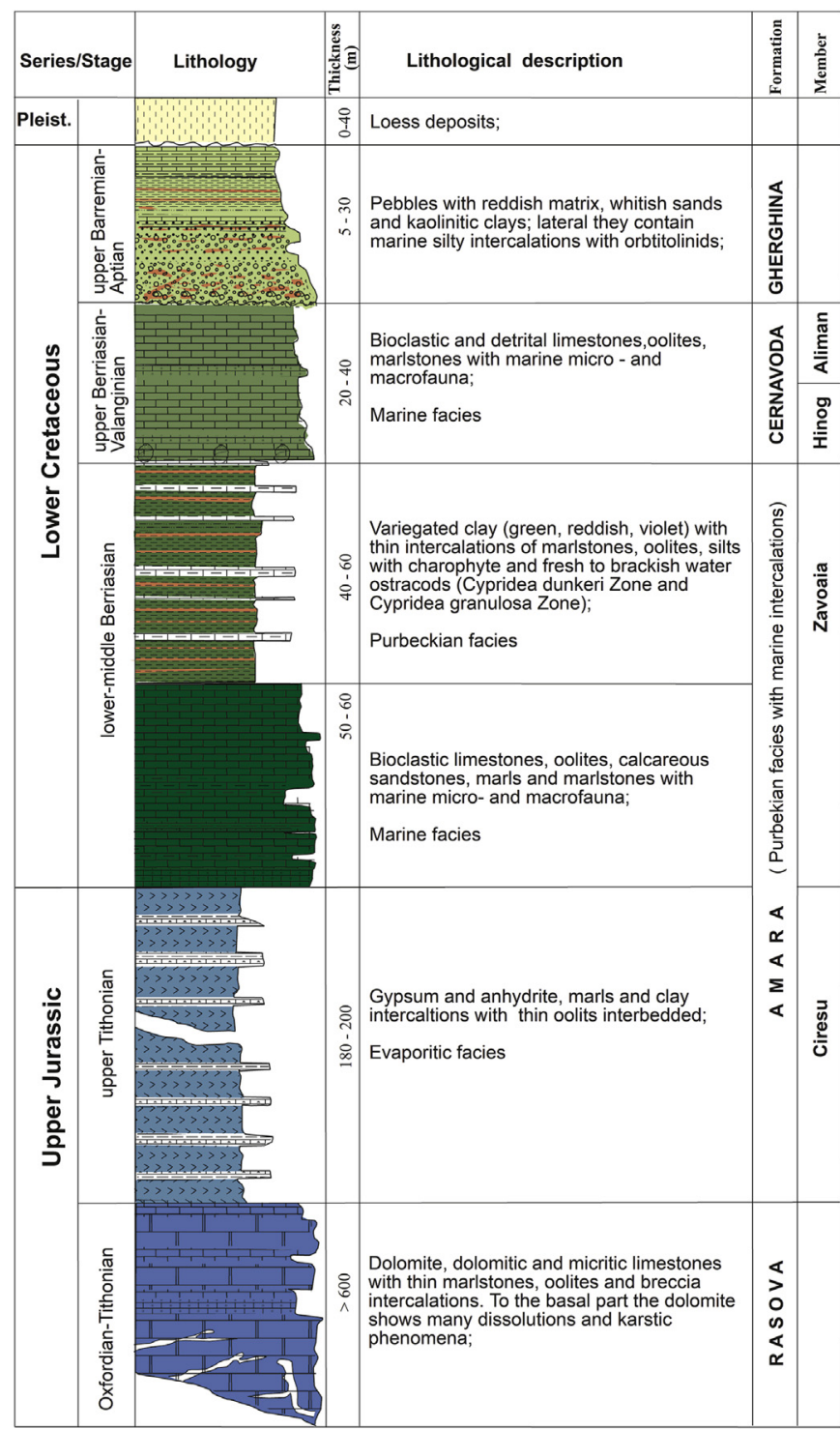

Fig. 2. General stratigraphic log near the locality of Cernavodă, showing the complete sedimentary sequence (modified from Stoica, 2007).

Gherghina and Ramadan formations (Figs 2 and 3). Two new shallow hydrogeological boreholes, PH3, and FMBAp5, have also been considered in this study. Both boreholes were dug close to Cernavodă village, intercepting mainly the subsurface Gherghina and Ramadan formations (Figs 1 and 3).

\section{Systematic palaeobotany}

Twenty charophyte species have been identified, described, and illustrated from the variegated interval of the Zăvoaia Member (Amara Formation) and the Gherghina Formation in South Dobrogea (south-eastern Romania).

Family ‘Porocharaceae’ Grambast, 1962

Genus Feistiella Schudack, 1986

Feistiella bijuescensis Schudack, 1986

Fig. 4A-E

Material. Several well-preserved gyrogonites were recovered from 14 samples in drill cores F1, F6, F8, F106, and F130 (Table 1).
Twenty-two gyrogonites from the sample Nazarcea F6/113 were measured.

Description. Gyrogonites are large, 681-892 $\mu \mathrm{m}$ high (mean 802 $\mu \mathrm{m}$ ) and 487-709 $\mu \mathrm{m}$ wide (mean $645 \mu \mathrm{m}$ ), vase-shaped, prolatespheroidal to subprolate, according to the gyrogonite terminology of Horn af Rantzien (1959) and Feist et al. (2005), with an isopolarity index (ISI) ranging between 119 and 140 (mean 126). The gyrogonite's maximum width is located just below the equator. The apex is slightly tapering and truncated. It displays a large roseshaped apical pore measuring $130 \mu \mathrm{m}$ in diameter (Fig. 4A) with the spiral cells reaching its rim and turning inside the pore. The base is rounded or slightly tapering. Spiral cells are concave, $85 \mu \mathrm{m}$ wide, and separated by protruding narrow intercellular ridges (Fig. $4 \mathrm{~B}$ and C). Laterally, 10 to 12 (commonly 11) convolutions are visible (Fig. 4B and C). Basal pore is small and pentagonal in shape, $81 \mu \mathrm{m}$ in diameter (Fig. 4D). An undivided pentagonal, slightly rounded basal plate, $100 \mu \mathrm{m}$ in diameter, can be observed from the inside of the gyrogonite (Fig. 4E).

Remarks. F. bijuescensis shares morphometric parameters with the species Porochara jargorensis Shaikin et Saidakovsky, 1976 in Shaikin (1976) or Porochara jaccardi (Heer, 1865) Mojon, 1989, as reported in Lower Cretaceous deposits from the Pre-Dobrogean Basin by Shaikin (1976) and from the South Dobrogea Basin by Avram et al. (1993), respectively. However, description and illustrations of these taxa in the aforementioned publications do not provide any information about the basal plate, which is the key parameter distinguishing genus Feistiella. In the future, a revision of the Shaikin and Avram collections should be performed in order to check that the species reported by these authors really are equivalent to $F$. bijuescensis. This species clearly differs from the Upper Cretaceous F. malladae, which is considerably larger $(200 \mu \mathrm{m})$ and displays a more rounded shape and a lower number of convolutions than F. bijuescensis.

Distribution. F. bijuescensis was first reported and described by Schudack (1986) from the upper Berriasian of Bijuesca, Iberian Chain (Aragón, Spain). Herewith we provide the first record of $F$. bijuescensis outside its type locality.

Age. Late Berriasian (Schudack, 1986).

\section{Feistiella sp.}

\section{Fig. $4 \mathrm{~F}-\mathrm{H}$}

Material. A small number of gyrogonites were recovered from two samples in the drill boreholes F1 and F31 (Table 1). Three specimens were measured from the sample Saligny F1/74-75.5.

Description. Gyrogonites are small, $600 \mu \mathrm{m}$ high and $485 \mu \mathrm{m}$ wide on average, showing a prolate-spheroidal shape with an ISI of 127 (Fig. 4G). The gyrogonite's maximum width occurs in the equator. The apex is truncated, showing a large rose-shaped apical pore of $130 \mu \mathrm{m}$ in diameter (Fig. 4F). The base is rounded, showing a small pentagonal basal pore (Fig. $4 \mathrm{H}$ ). Nine concave spiral turns can be observed in the lateral view. Spiral cells are $127 \mu \mathrm{m}$ wide and are separated by narrow intercellular ridges. A pentagonal, rounded and undivided basal plate can be observed inside the gyrogonite. Remarks. This species displays similar morphological parameters to F. bijuescensis. However, the gyrogonites are clearly smaller in size (ca. $200 \mu \mathrm{m}$ in height), showing fewer spiral turns when observed laterally. The lower number of specimens recovered hinders a more detailed determination.

Distribution. This study represents the first report of this species. Age. Berriasian, based on the associated charophyte and ostracod assemblages.

Genus Latochara Mädler, 1955 emend. Feist et Cubaynes, 1984 Latochara sp.

Fig. 4I 


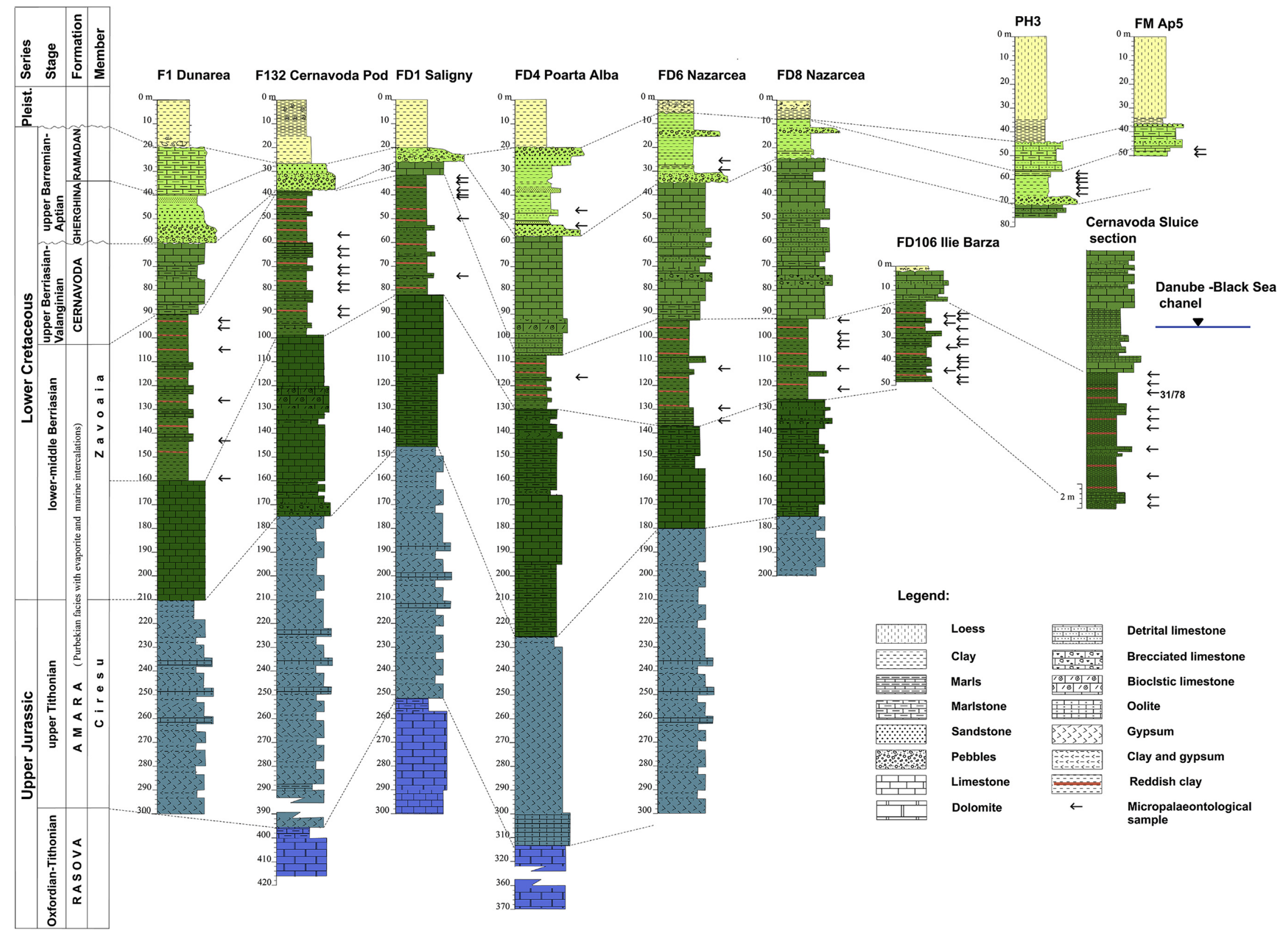




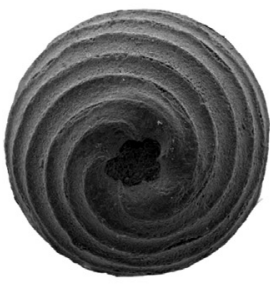

A

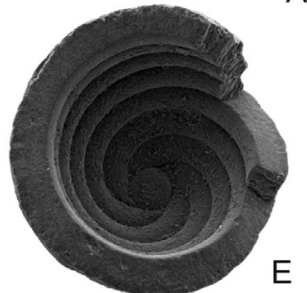

E

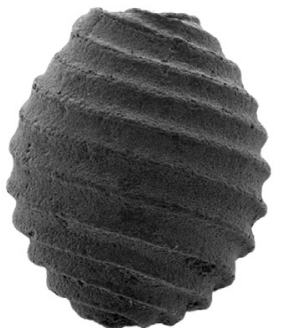

B

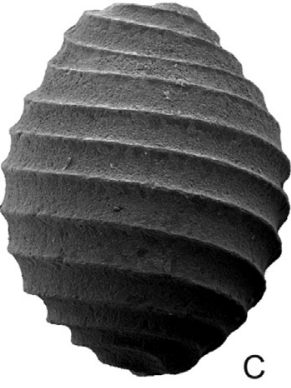

C

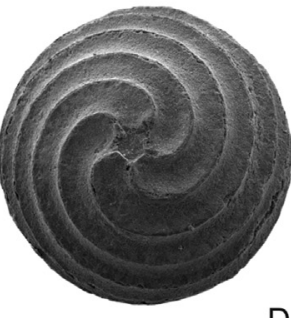

D
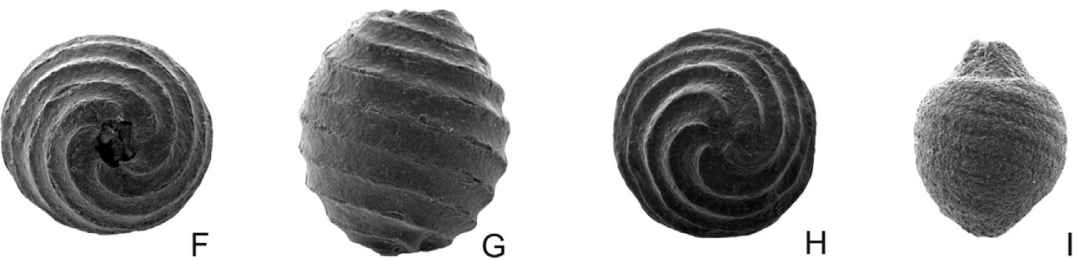

$\mathrm{H}$

$500 \mu \mathrm{m}$

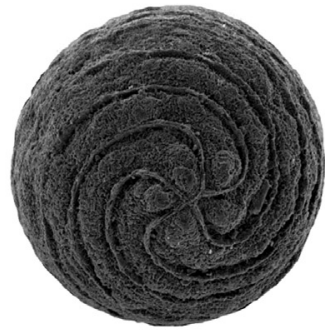

J
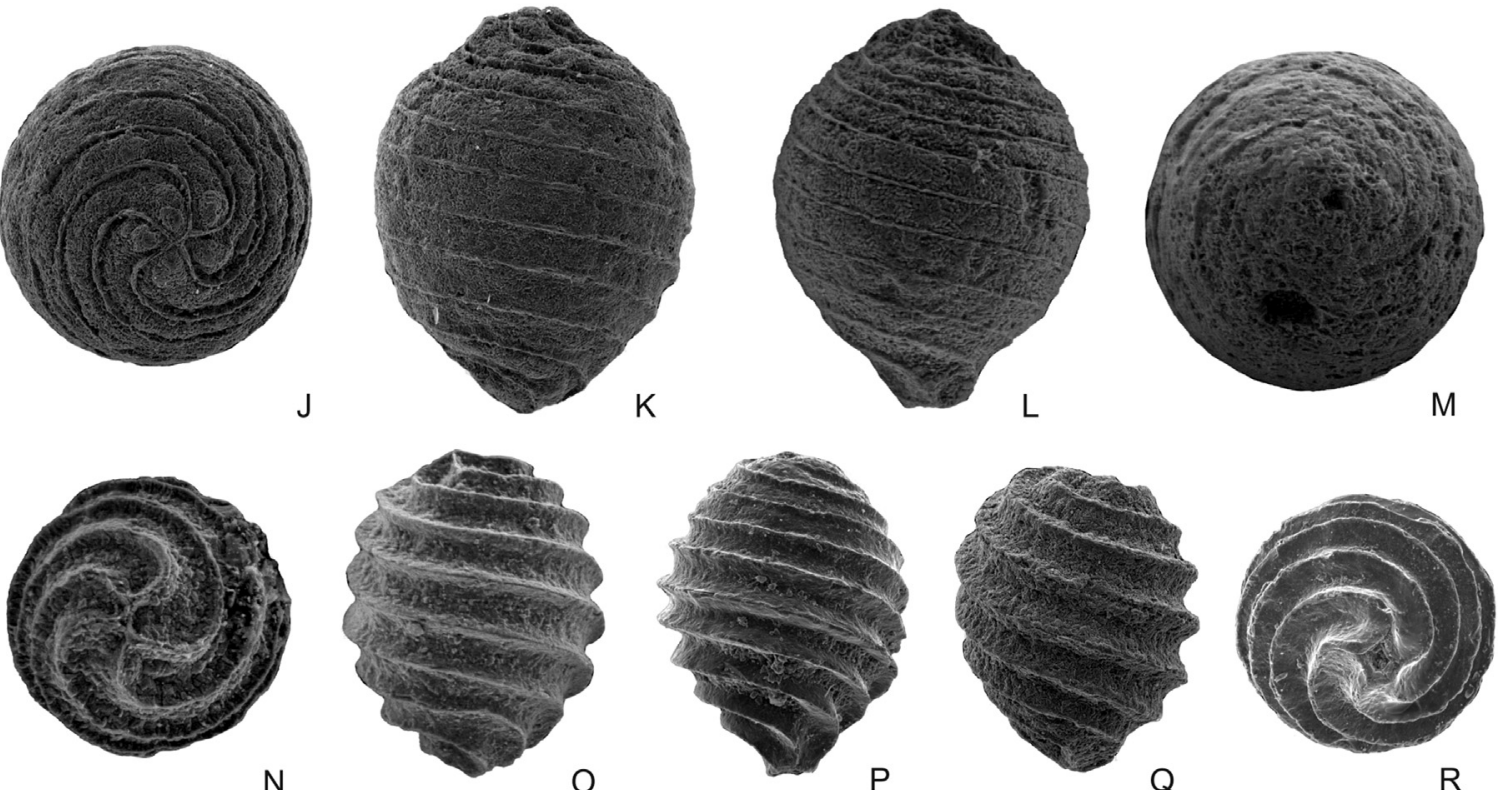

N
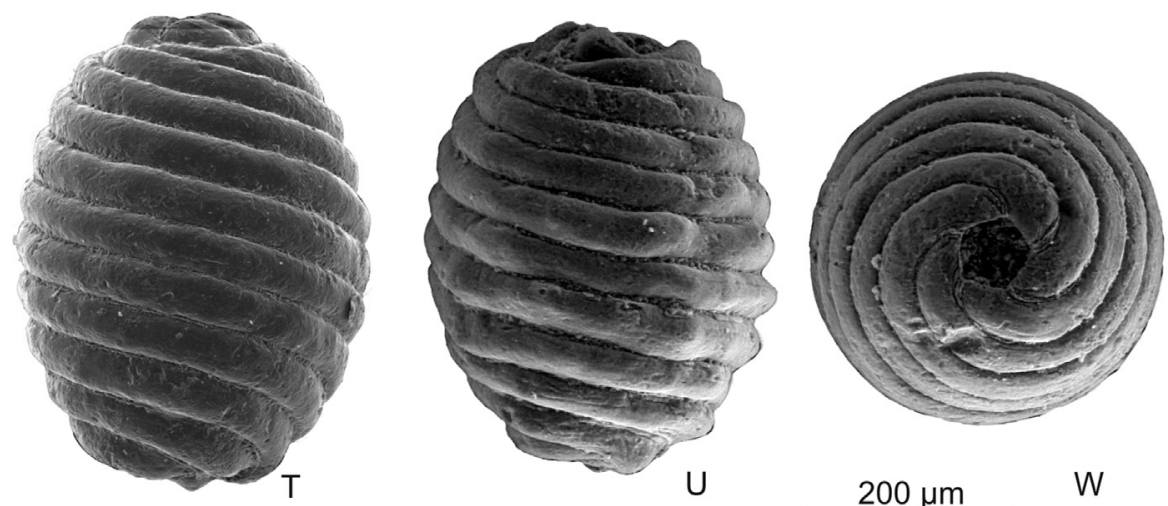

$200 \mu \mathrm{m}$

W

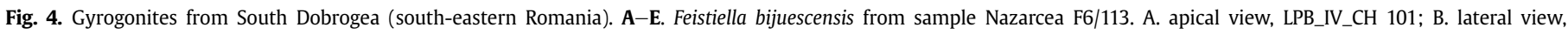

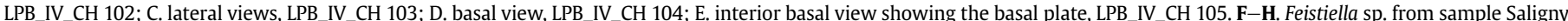

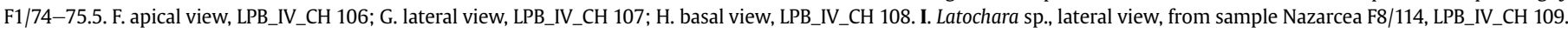

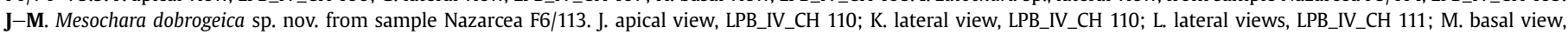

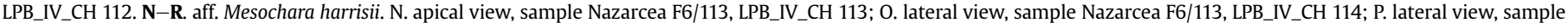

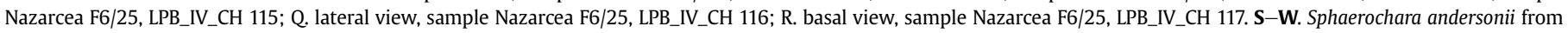
sample Nazarcea F6/25. S. apical view, LPB_IV_CH 118; T. lateral view, LPB_IV_CH 118; U. lateral view, LPB_IV_CH 119; W. basal view, LPB_IV_CH 120. 
Material. A few poorly preserved gyrogonites were collected from sample Nazarcea F8/114 (Table 1). Two specimens were measured. Description. Gyrogonites are small, $377 \mu \mathrm{m}$ in length and $310 \mu \mathrm{m}$ in width on average. They display subglobular shape and an ISI of 122. Nine or ten spiral turns can be observed in the lateral view (Fig. 4I). The gyrogonite shape and apical structure warrant the inclusion of these gyrogonites in the genus Latochara. At the rim of the summit, spiral cells turn abruptly upwards into an almost vertical position to form a small pyramidal projection in the centre (Fig. 4I). The apical pore cannot be observed due to the poor preservation of the gyrogonites. The base is slightly tapering or could be rounded.

Remarks. Poor preservation and an insufficient number of gyrogonites from only one sample hinder a detailed taxonomic attribution and comparison with other Latochara species.

Distribution. Latochara gyrogonites have been found in several Mesozoic basins in France, Ukraine, and the USA. It also seems to occur in the Palaeocene of China (Feist et al., 2005 and references therein).

Age. The genus Latochara displays a wide biostratigraphic range, occurring in Triassic to Palaeocene sedimentary sequences (Feist et al., 2005). However, in Europe, it disappeared during the Berriasian (Schudack, 1993).

Family Characeae (Richard ex C. Agardh, 1824) emend. MartínClosas et Schudack, 1991

Subfamily Charoidae Al. Braun in Migula, 1897

Genus Mesochara Grambast, 1962

Mesochara dobrogeica Sanjuan, Vicente, Pérez-Cano, Stoica et Martín-Closas, sp. nov.

Fig. 4J-M

Derivation of name. From the type locality in the Dobrogea area (south-eastern Romania).

Holotype. LPB-_IV_CH 110, collection number of the Laboratory of Palaeontology of Bucharest (Fig. 4J and K).

Paratypes. Numbers LPB_IV_CH 111 and LPB_IV_CH 112, collection number of the Laboratory of Palaeontology of Bucharest (Fig. 4L and M).

Repository. Laboratory of Palaeontology of Bucharest (University of Bucharest, Romania).

Type locality. Nazarcea (borehole F6/113).

Type stratum. Marl interval of the Zăvoaia Member located at 113$\mathrm{m}$-depth in the Nazarcea F6 borehole. This species also occurs in another borehole (F8) in the same locality at a depth of 98-m (Table 1).

Diagnosis. Small-sized gyrogonites, ovoidal in shape, with slightly pointed apex and base, and ornamented with apical tubercles. Spiral cells concave, showing nine to eleven turns in the lateral view, without periapical modifications.

Description of the type population. Thirteen gyrogonites were measured. Gyrogonites are ovoidal (subovoidal) in shape and small in size, 328-428 $\mu \mathrm{m}$ high (mean $385 \mu \mathrm{m}$ ) and 254-343 $\mu \mathrm{m}$ wide (mean $310 \mu \mathrm{m}$ ), subprolate, with an ISI ranging between 110 and 136 (mean 124). Nine to eleven spiral turns can be observed laterally (Fig. 4K and L). The apex is slightly pointed, showing isolated and small apical tubercles (Fig. 4J). Spiral cells do not show any periapical modification. The base is tapering and pointed. The basal pore is very small and pentagonal in shape. The basal plate is unknown.

Remarks. Morphological parameters of this species (size, apex closed by unmodified periapical cells, pointed base and small basal pore) suggests its inclusion in the genus Mesochara, although the basal plate is needed to confirm this. The presence of well-defined apical tubercles distinguishes this species from other Cretaceous Mesochara species and represents the oldest occurrence of an ornamented gyrogonite in the fossil record of the Charoidae/ Chareae Al. Braun in Migula, 1897.

Distribution. This is the first known occurrence of this species.

Age. Early Cretaceous (Berriasian), based on the associated charophytes and ostracods.

\section{aff. Mesochara harrisii (Mädler, 1952) Shaikin, 1967}

Fig. $4 \mathrm{~N}-\mathrm{R}$

Material. Several gyrogonites were extracted from all the studied drilling boreholes. However, they occur only in moderate abundance (Table 1). Ten gyrogonites were measured from sample Saligny F1/74-75.5 and ten specimens from sample Nazarcea F6/113. Description. Gyrogonites are very small, 235-377 $\mu \mathrm{m}$ high (mean $317 \mu \mathrm{m}$ ) and $189-287 \mu \mathrm{m}$ wide (mean $241 \mu \mathrm{m}$ ), subprolate to prolate, with an ISI ranging between 114 and 158 (mean 128). Six to nine (commonly eight) spiral turns can be observed in the lateral view (Fig. 4O-Q). The apex is rounded or slightly pointed, showing the junction of apical cells without any periapical modification (Fig. $4 \mathrm{~N}$ ). The base is pointed and occasionally projected, forming a short basal column. The basal pore is pentagonal in shape and very small in diameter (Fig. 4R). The basal plate has not been observed, making the genus attribution of these gyrogonites to Mesochara (undivided basal plate) or Tolypella (divided basal plate in Tolypella section Tolypella) difficult, as already pointed out by Martín-Closas et al. (2018). The gyrogonites studied can be compared to Mesochara stipitata (Wang, 1965) Wang, 1981 since some of them display a small basal projection. However, this character is not regularly present in the populatins studied. On the other hand, $M$. harrisii can be distinguished from the contemporary species Mesochara voluta (Peck, 1937) Grambast, 1965 since the latter shows a characteristic subovoidal shape and a lower ISI.

Distribution. M. harrisii is considered a cosmopolitan species. It has been identified in Lower Cretaceous non-marine deposits from western European basins (Iberian Chain, Subalpine Chains, and Jura Mountains), China, Japan, and the United States (Martín-Closas, 2000).

Age. Early Cretaceous (Martín-Closas, 2000).

Subfamily Nitelloideae Al. Braun in Migula, 1897

Genus Sphaerochara (Mädler, 1952) emend. Soulié-Märsche, 1989 Sphaerochara andersonii Feist, Lake et Wood, 1995 Fig. 4S-W

Material. A small number of gyrogonites were recovered from two samples in Nazarcea, i.e., F6/113 and F6/25 (Table 1). Twenty-one specimens were measured from the sample Nazarcea F6/25.

Description. Gyrogonites are small, 363-471 $\mu \mathrm{m}$ high (mean 411 $\mu \mathrm{m}$ ) and 291-353 $\mu \mathrm{m}$ wide (mean $316 \mu \mathrm{m}$ ), subprolate to prolate in shape, with an ISI ranging between 115 and 148 (mean 133). Spiral cells are $133 \mu \mathrm{m}$ wide (Fig. 4T), usually convex or flat, occasionally thick, forming a wavy mid-cellular crest (Fig. 4U). Eleven to fourteen (commonly twelve) spiral turns can be observed in the lateral view (Fig. 4T and $\mathrm{U}$ ). The gyrogonite base is rounded, showing a large pentagonal basal pore of up to $70 \mu \mathrm{m}$. The basal plate is in the shape of a pentagonal prism, very large, and can be distinguished from the outside. Spiral cells show a slight narrowing at the periapical area of the gyrogonite, bearing well-developed apical nodules, which may form a rosette (Fig. 4S).

Distribution. This species was first reported by Feist et al. (1995) from a drilling core in the English Weald (UK). Martín-Closas (2000) recovered S. andersonii from lacustrine deposits in the Iberian Chain (Spain). This study describes $S$. andersonii in eastern Europe for the first time, which enhances its biostratigraphic significance regarding basin correlation.

Age. Hauterivian to late Barremian (Martín-Closas, 2000). 
Table 1

List of charophyte taxa and their relative abundance based on a semi-quantitative visual estimation.

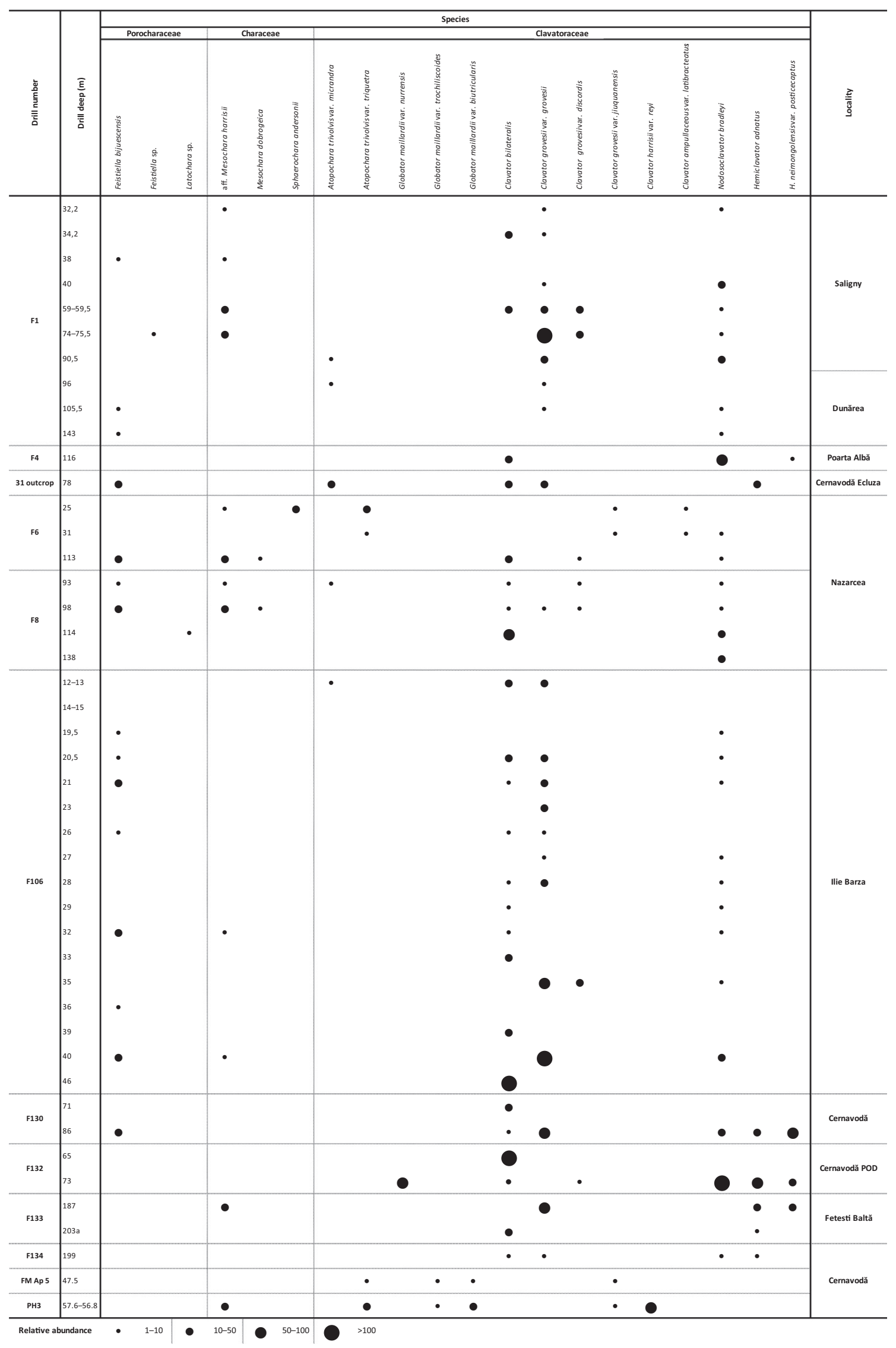


Family Clavatoraceae Pia, 1927

Subfamily Atopocharoidae Grambast, 1968 emend. Martín-Closas ex Schudack, 1993

Genus Globator Grambast, 1966

Globator maillardii (Saporta, 1981) Grambast, 1966 emend. MartínClosas ex Schudack, 1993

Globator maillardii var. murrensis Pecorini, 1969

Fig. 5A-D

Material. Several well-preserved utricles have been recovered from the sample F132/73 in Cernavodă (Table 1). Seven utricles of this species have been measured for the description.

Description. Gyrogonites are large and globular, bottle-shaped, noncalcified; known from their impressions on the internal wall of the utricle. Utricles are very variable in size, ranging between 882-1417 $\mu \mathrm{m}$ high (mean $1247 \mu \mathrm{m}$ ) and 764-1078 $\mu \mathrm{m}$ wide (mean $934 \mu \mathrm{m}$ ), with an average ISI of 133 . The utricle displays a subspherical or fusiform shape, showing a long apical neck (Fig. 5B and C). Occasionally, the apical neck can be very extended (Fig. 5C). The apical pore (Fig. 5A) is circular in shape and large in diameter (ca. $190 \mu \mathrm{m}$ ). The utricle is organised in three units of symmetry, which are clearly recognised from its basal view (Fig. 5D). Each unit consists of one diamond-shaped to long pentagonal, short basal cell, to which three elongated cells are attached. Two more elongated cells embrace this central structure and can be subdivided into two parts by a suture above the equator of the utricle (see the arrow in Fig. 5B). The five elongated cells (two lateral and three central) of each unit coil clockwise from the basal part of the utricle to the apex. Nine or ten turns can be observed in the lateral view (Fig. 5B and $\mathrm{C}$ ).

Distribution. Utricles of this species were first illustrated and named "charophyte oogoniä from the region studied by Malz (1969). This species was first described formally from La Nurra d'Alguer, in Sardinia (Italy) and later reported in the Iberian Chain, Catalan Coastal Chains, Basque-Cantabrian Chain, Prebetic Chain (Spain), Lusitanian Basin (Portugal), and Jura Mountains in France and Switzerland (Martín-Closas, 2000 and references therein).

Age. Late Berriasian, based on ammonite correlation in the Jura Mountains, Switzerland (Détraz and Mojon, 1989).

Globator maillardii var. trochiliscoides (Grambast, 1966) MartínClosas, 1996

Fig. 5E-H

Material. A few well-preserved utricles have been recovered from only one sample, Cernavodă FMAp 5/47.5 m (Table 1). Two utricles have been measured for the description.

Description. Gyrogonites are globular, non-calcified and known from their impressions on the internal wall of the utricle. Utricles are globular, bottle-shaped and very large, at $1026 \mu \mathrm{m}$ high and 923 $\mu \mathrm{m}$ wide, with an ISI of 111 (Fig. 5F and G), displaying a short and broad apical neck. Apical pore is large ( $115 \mu \mathrm{m}$ in diameter) and circular in outline (Fig. 5E). The base is rounded or slightly pointed, showing a small basal pore (Fig. $5 \mathrm{H}$ ). The utricle is organised in three identical units of symmetry, which can be recognised at the base. Each unit is formed by five elongated cells; three in a central position, converging to the basal pore without reaching it, flanked by two more elongated cells, one at either side of this central group and directly attached to the basal pore. The 15 utricle cells coil clockwise to the apex, displaying 17 convolutions in the lateral view (Fig. 5F and G).

Distribution. This species has already been mentioned by Avram et al. (1993) in South Dobrogea (south-eastern Romania). However, no clear illustration or proper description was provided. G. maillardii var. trochiliscoides is abundant in Barremian lacustrine deposits from the Iberian Chain (Spain), Algarve (Portugal), Subalpine Chain
(France), Jura Mountains (Switzerland), Middle and High Moroccan Atlas (Morocco), and Tunisian Atlas (Tunisia), and it represents a characteristic taxon of the western islands of the Cretaceous Tethyan Archipelago (Martín-Closas, 2000).

Age. Early Barremian to early Aptian (Martín-Closas, 2000).

Globator maillardii var. biutricularis Vicente et Martín-Closas, 2013

Fig. 5I-K

Material. A few utricles have been recovered from one sample from Cernavodă, i.e., FM Ap5/47.5 m (Table 1). Two utricles of this variety have been measured for the description.

Description. Utricles are very large, $1105 \mu \mathrm{m}$ high and $822 \mu \mathrm{m}$ wide, with an ISI of 135, and globular in shape (Fig. 5I and J). The utricle structure is identical to that of the var. trochiliscoides but it shows a characteristic uncalcified ring around the basal pore (Fig. 5K), which was wrongly interpreted as representing a superimposed utricle layer by Vicente and Martín-Closas (2013), as recently noted by Pérez-Cano et al. (2020).

Distribution. This variety of Globator maillardii has so far been reported in the Iberian Chain in NE Spain (Vicente and Martín-Closas, 2013) and in one locality of the Central Tunisian Atlas (Trabelsi et al., 2016).

Age. Late Barremian to early Aptian (Vicente and Martín-Closas, 2013).

Genus Atopochara Peck, 1938.

Atopochara trivolvis (Peck, 1938) emend. Martín-Closas, 1996

Atopochara trivolvis var. micrandra (Grambast, 1967) MartínClosas, 1996

Fig. 5L and $\mathrm{M}$

Material. A few utricles from five samples in Saligny, Dunărea, Cernavodă, Nazarcea, and Ilie Barza (Table 1). Two utricles were measured from the outcrop sample Cernavodă Ecluza 31/78.

Description. Gyrogonites are globular, non-calcified and known from their impressions on the internal wall of the utricle. Utricles are very large, $1187 \mu \mathrm{m}$ high and $1109 \mu \mathrm{m}$ wide, and globular in shape (Fig. 5L and M). They display a triradiate symmetry. Each unit of symmetry is formed by three main branches attached to a short basal cell, directly connected to the basal pore. Each of the three main branches trifurcates once or twice, forming fork-like structures that bear the antheridia, as described by Grambast (1967, 1968). About ten to fifteen antheridial impressions can be recognised, each having a diameter of about $240 \mu \mathrm{m}$ and showing at least two out of four antheridial shields.

This species differs from its ancestor $A$. trivolvis var. horrida in its larger utricle size and also because the vegetative structure of $A$. trivolvis var. horrida is hidden by the larger size of the antheridial impressions on the utricle wall.

Distribution. This species has already been mentioned in South Dobrogea by Avram et al. (1993) and in the nearby Pre-Dobrogean Basin (Ukraine) by Shaikin (1976). A. trivolvis var. micrandra represents an extensively distributed taxon occurring in the northern part of the Cretaceous Tethyan archipelago. It has been reported in Spain (Iberian Chain, Catalan Coastal Chain, Basque-Cantabrian Chain and Prebetic Chain), Portugal (Algarve), Switzerland (Jura Mountains), and Italy (Sardinia) (Martín-Closas, 2000 and references therein).

Age. Early Berriasian to late Hauterivian (Martín-Closas, 2000 and references therein).

Atopochara trivolvis var. triquetra (Grambast, 1967) MartínClosas, 1996

Fig. $5 \mathrm{~N}-\mathrm{Q}$ 

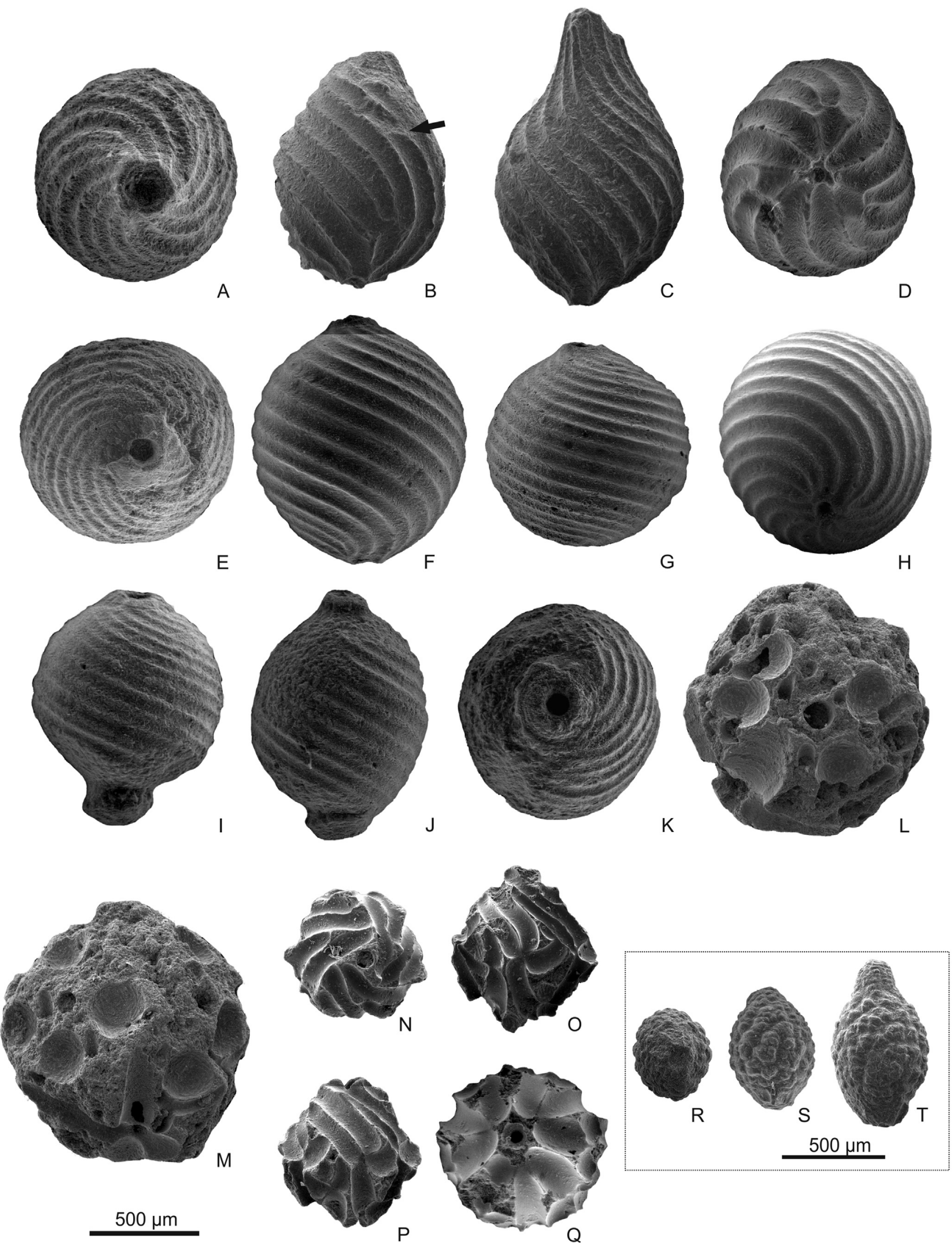

$500 \mu \mathrm{m}$ 
Material. Several utricles of this variety were recovered from four samples in Nazarcea and Cernavodă (Table 1). Six utricles were measured from sample Nazarcea F6/25.

Description. Gyrogonites are globular, non-calcified and known from their impressions on the internal wall of the utricle. Utricles are large and very variable in size, 673-1155 $\mu \mathrm{m}$ high (mean 866 $\mu \mathrm{m}$ ) and 663-985 $\mu \mathrm{m}$ wide (mean $759 \mu \mathrm{m}$ ), bi-tetrahedral in shape and with a triradiate symmetry formed by three identical bract-cell units (Fig. 50 and P). Each unit is formed by three equally large bract cells at the base, that are attached to the basal pore (Fig. 5Q). The two left-hand basal cells trifurcate with two long, helicoidal cells on the left and one short, rounded cell on the right. The third bract-cell unit bifurcates into two small diamond-shaped cells that flank a central cell bearing the impression of one antheridial shield. The antheridium marks are, in this case, smaller than in the variety A. trivolvis micrandra.

Distribution. A. trivolvis var. triquetra was found in the nearby PreDobrogean Basin in Ukraine by Shaikin (1976). Avram et al. (1993) reported it in South Dobrogea (Romania). This variety displays a worldwide distribution occurring in almost all continents except North America and Australia (Martín-Closas and Wang, 2008 and references therein).

Age. Latest Hauterivian to early Aptian (Martín-Closas, 2000; Martín-Closas et al., 2009).

Subfamily Clavatoroidae (Grambast, 1969) emend. Martín-Closas ex Schudack, 1993

Genus Nodosoclavator Maslov, 1961

Nodosoclavator bradleyi (Harris, 1939) Grambast, 1969

Fig. 5R-T

Material. It represents a common taxon occurring in all the localities and drilling boreholes studied (Table 1). Seven utricles have been measured from sample F4/116 in Poarta Albă.

Description. This species shows a clavatoroid gyrogonite. Utricles are elongated and bottle-shaped (Fig. $5 \mathrm{~S}$ and $\mathrm{T}$ ), very variable in size, 586-821 $\mu \mathrm{m}$ high (mean $623 \mu \mathrm{m}$ ) and 351-478 $\mu \mathrm{m}$ wide (mean $385 \mu \mathrm{m}$ ), with an ISI of 167 . The utricle is mostly formed by a nodular layer, with nodules roughly aligned following the spiralcell sutures (Fig. 5S and T). The superimposed, structured utricle layer can be observed only at its base. It is formed by small, digitated bract cells which are arranged radially around the basal pore.

Distribution. N. bradleyi is a cosmopolitan taxon occurring in European and Chinese basins (Wang et al., 1976; Huang, 1985; MartínClosas, 2000 and references therein). Moreover, this species has recently been reported in the Western Interior Basin in the USA (Martín-Closas et al., 2013). Peck (1957) found this species (under the name of Clavator nodosus) in the Aptian from the Western Interior.

Age. Tithonian-Aptian (Martín-Closas, 2000).

Genus Clavator (Reid et Groves, 1916) emend. Martín-Closas ex Schudack, 1993

Clavator bilateralis Peck, 1957 emend Martín-Closas, Sames et Schudack 2013

Fig. 6A-D
Material. This species occurs abundantly in almost all the drilling boreholes studied (Table 1). Fourteen utricles from sample Nazarcea F8/14 were measured for the description.

Description. This species shows a clavatoroid gyrogonite. Utricles are small, showing a clear bilateral symmetry. In the lateral view they are 430-728 $\mu \mathrm{m}$ high (mean $513 \mu \mathrm{m}$ ) and 373-527 $\mu \mathrm{m}$ wide (mean $472 \mu \mathrm{m}$ ). The utricle consists of an internal nodular layer covered completely by a structured layer. This layer is formed by the impression of the phylloid in an adaxial position, an abaxial elongated bract cell opposite it and two lateral composite bract-cell units displaying a pinnate structure (Fig. 6B and C). Each lateral bract-cell unit is formed by a single wide, vertical cell in the centre, attached to the utricle base, occasionally reaching mid-height of the utricle, and bearing one lancet-shaped cell at the top and two to three symmetrical pairs of elongated bract cells on each side, arranged opposite each other (Fig. $6 \mathrm{~B}$ and $\mathrm{C}$ ). Both the abaxial long cell and the lateral composite bract-cell units are attached to a rounded basal pore (Fig. 6D). The apical pore is large $(100 \mu \mathrm{m}$ in diameter) and displays a circular outline (Fig. 6A).

Remarks. The utricle structure of this species in the South Dobrogea Basin corresponds well to the populations described by Peck (1957) and Martín-Closas et al. (2013), from the Lakota and Cedar Mountain formations in the USA. The main difference between both North American populations and the Romanian populations studied here, lies in the number of pinnate cells at the lateral bract-cell units, which ranges from five to seven in Romanian utricles, while the American populations show a wider range of intraspecific variation, including utricles with only three pinnate cells (MartínClosas et al., 2013). The latter correspond, in fact, with the holotype designated by Peck (1957). However, the illustrations of this species provided by Avram et al. (1993) suggest that this morphotype may also occur in Romania.

Distribution. Avram et al. (1993) had already cited C. bilateralis (under the name of its younger synonym, Clavator minutus) in South Dobrogea (south-eastern Romania). Shaikin (1976) also found this taxon in the Pre-Dobrogean Basin (south-eastern Ukraine). However, these references were not considered in subsequent charophyte studies, probably due to insufficient description and illustration. C. bilateralis has been re-defined and illustrated with modern techniques only very recently from the Western Interior Basin of the United States by Martín-Closas et al. (2013). The present study confirms the occurrence of this species outside North America.

Age. Early Berriasian to earliest Valanginian (Martín-Closas et al., 2013).

Clavator grovesii (Harris, 1939) emend. Schudack, 1993

Clavator grovesii var. grovesii (Harris, 1939) Martín-Closas, 1996 Fig. 6E-K

Material. Well-preserved utricles of this variety dominate in many samples of the studied localities (Table 1). Sixteen utricles from the sample Saligny F1/74-75.5 were measured for the description.

Description. Gyrogonites are clavatoroid, while utricles are oval and laterally flattened (Fig. 6H-K). They are medium in size, 489-674 $\mu \mathrm{m}$ high (mean $561 \mu \mathrm{m}$ ) and 390-517 $\mu$ m wide (mean $466 \mu \mathrm{m}$ ). The utricle is formed of an internal nodular layer and an external structured layer displaying bilateral symmetry. The external layer is

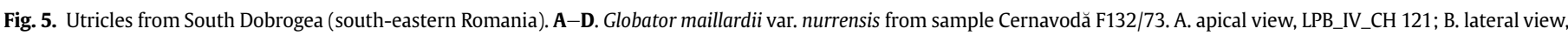

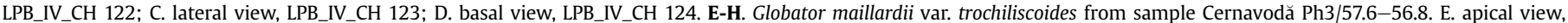

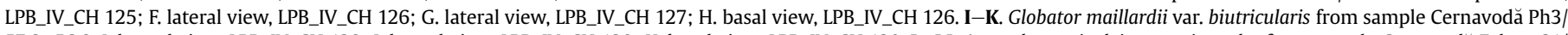

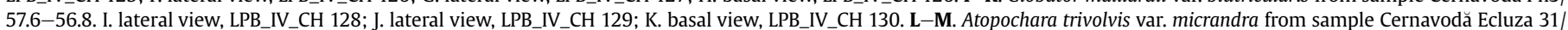

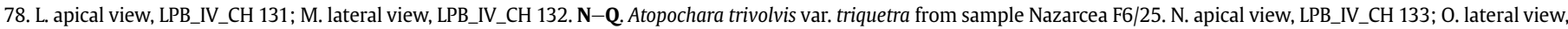

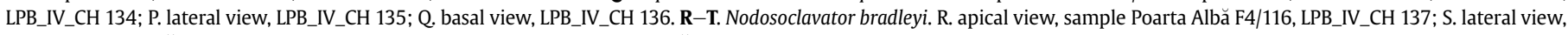
sample Poarta Albă F4/116, LPB_IV_CH 138; T. lateral view, sample Cernavodă F130/86, LPB_IV_CH 139. 

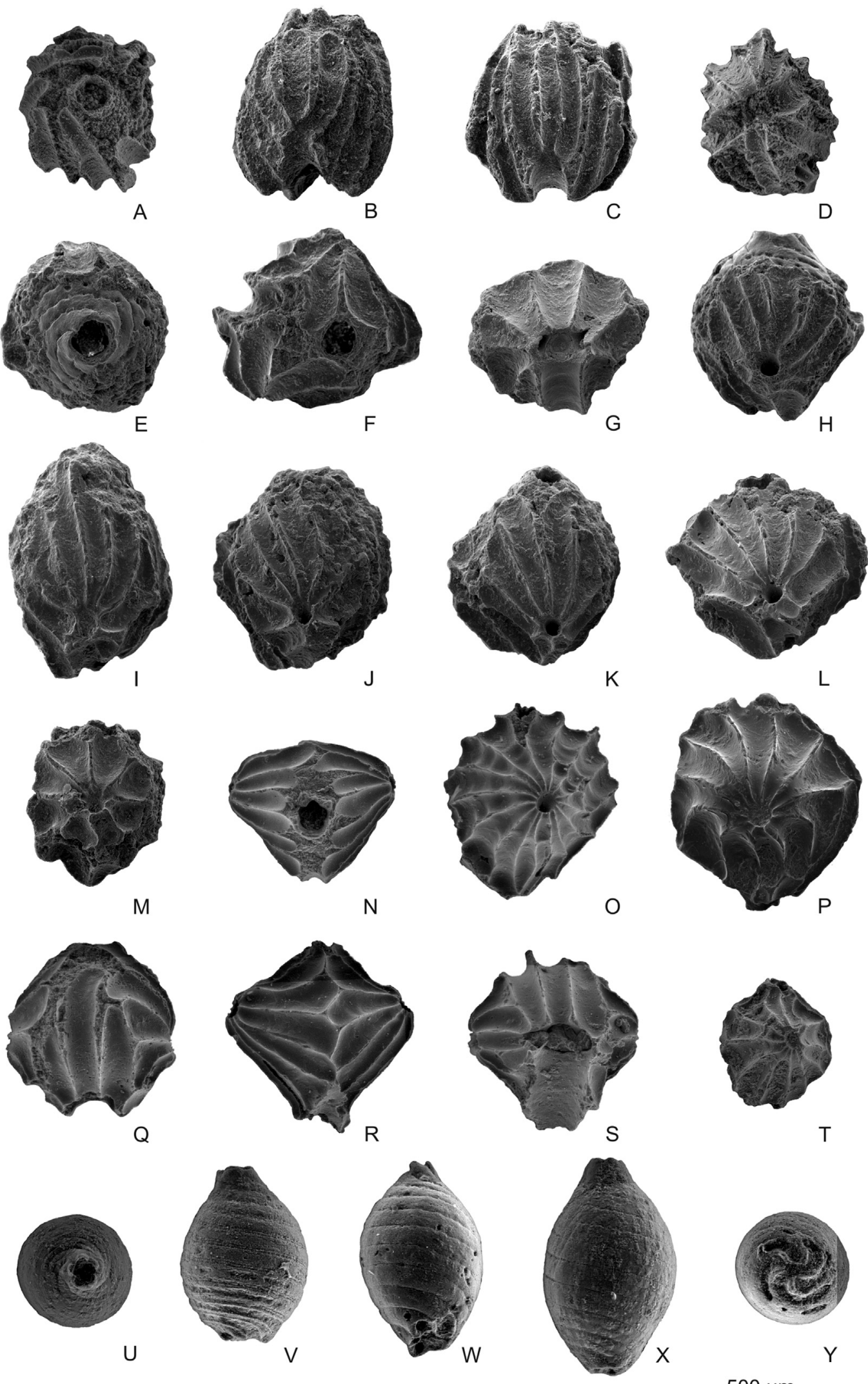
formed by a portion of the branchlet and three bract cells connected to the basal pore (Fig. 6F). One of the bract cells is located in an abaxial position, opposite the branchlet. The other two bract cells are shorter and are located in a lateral position, each bearing a lateral fan at the tip. Eight lancet-shaped fan cells can be distinguished, completely or almost completely covering the utricle surface (Fig. $6 \mathrm{H}-\mathrm{K}$ ). On each side of the lateral bract cell a smaller and wider cell can be observed in the lateral view. The apical pore is large (Fig. $6 \mathrm{E}$ and F), $98 \mu \mathrm{m}$ in diameter, sometimes showing a roseshaped outline (Fig. 6E). The basal pore is also large, $120 \mu \mathrm{m}$ in diameter, showing the base of the internal gyrogonite and its basal plate (Fig. 6G).

Distribution. C. grovesii var. grovesii represents a cosmopolitan taxon occurring in several western European basins, China, and North America (Martín-Closas et al., 2013; Martín-Closas, 2015). This species has also been cited in South Dobrogea (south-eastern Romania) by Avram et al. (1993). However, no detailed description or illustration was provided by these authors. The present study confirms the occurrence of this variety of Clavator grovesii in the eastern Cretaceous Tethyan archipelago.

Age. Tithonian to earliest Valanginian (Martín-Closas et al., 2013).

Clavator grovesii var. discordis (Shaikin, 1976) Martín-Closas, 1996 Fig. 6L-M

Material. It occurs in minor amounts, associated with the previous variety $C$. grovesii var. grovesii, in several samples from almost all localities (Table 1). Four specimens from sample Nazarcea F6/113 were measured.

Description. The fructification of this variety has a similar utricle structure to the previous variety, except for the lateral bract-cell fans. Eight lancet-shaped fan cells can be distinguished covering the utricle surface, six elongated cells are arranged upwards and two short cells downwards at the base of the fan (Fig. 6L and M). On each side of the lateral bract cell, a smaller and wider cell can be observed in the lateral view.

Distribution. This species was first described by Shaikin (1976) in Odessa (Ukraine). Later, it was widely reported in non-marine deposits from western European countries such as Spain, Portugal, Germany, France, and the United Kingdom (Martín-Closas, 2000 and references therein). Moreover, Wang and Lu (1982) found this species in China.

Age. According to Schudack (1993) this variety would have extended through the whole Berriasian.

Clavator grovesii var. jiuquanensis (Wang, 1965) Grambast, 1970 emend. Martín-Closas, 1996.

Fig. $6 \mathrm{~N}-\mathrm{T}$

Material. A few utricles in four samples from Nazarcea and Cernavodă (Table 1). Six utricles were measured from the sample Cernavodă FMAp5/47.5.

Description. Gyrogonites are clavatoroid. Utricles are medium in size, 419-650 $\mu \mathrm{m}$ high and 365-618 $\mu \mathrm{m}$ wide, bi-conical in shape, and formed of two layers, i.e., the internal nodular layer and the external structured layer. The external layer contains the impressions of the phylloid and three bract cells, including an abaxial bract cell opposite the phylloid (Fig. 6Q) and two lateral bract-cell units which protrude to form a cone at each side of the utricle and were called shields by Grambast (1970). Each of these lateral units bears 11 to 15 elongated radial cells at the tip (Fig. 60, P and $\mathrm{T}$ ), which are generally equidimensional and reach both the base and the apex of the utricle, interdigitating with the corresponding cells of the opposite shield in the abaxial side. The basal pore is large (ca. $112 \mu \mathrm{m}$ in diameter) and the apical pore is ca. 84 $\mu \mathrm{m}$ in diameter, showing a rose-shaped contour (Fig. $6 \mathrm{~N}$ and $\mathrm{S}$ ). Remarks. A few utricles of the studied population show small basal cell impressions, suggesting that these populations contain some primitive forms of the variety, closer to its predecessor $C$. grovesii var. gautieri (Grambast, 1970).

Distribution. C. grovesii var. jiuquanensis had already been found in South Dobrogea by Neagu and Georgescu-Donos (1973). Later, Shaikin et al. (1992) reported this species in the nearby PreDobrogean Basin, located about $200 \mathrm{~km}$ north-east of the studied basin, in Ukraine. This species is extensively distributed in Europe and Asia (Martín-Closas, 2015 and references therein).

Age. Late Barremian to early Aptian (Martín-Closas, 2015).

Clavator harrisii var. reyi (Grambast-Fessard, 1980) Martín-Closas, 1996

Fig. 6U-Y

Material. Several utricles from sample Cernavodă PH3/57.6-56.8 (Table 1). Three utricles were measured.

Description. The fructification consists of an ellipsoidal to bottleshaped, medium-sized clavatoroid gyrogonite, 512-637 $\mu \mathrm{m}$ high and 356-387 $\mu \mathrm{m}$ wide, devoid of any utricle layer in almost all specimens of the populations. The gyrogonite shows convex tubular spiral cells (the so-called "Ringstruktur" calcification of Schudack, 1993), separated by characteristic undulated sutures (Fig. $6 \mathrm{~V}, \mathrm{~W}$ and $\mathrm{X}$ ) and a wide apical neck with a rose-shaped apical pore of $63 \mu \mathrm{m}$ in diameter (Fig. 6U).

Distribution. This variety of $C$. harrisii has been found in several localities in the western part of the Cretaceous Tethyan archipelago, i.e., Iberian Chain (Spain), Algarve Basin (Portugal), Lusitanian Basin (Portugal), and Central Tunisian Atlas (Trabelsi et al., 2016). The present study also reveals the occurrence of this variety in the eastern part of the Cretaceous Tethyan archipelago.

Age. Late Barremian to early Aptian (Martín-Closas, 2000).

Clavator ampullaceus (Grambast et Lorch, 1968) Martín-Closas, 1996 Clavator ampullaceus var. latibracteatus Sanjuan, Vicente, PérezCano, Stoica et Martín-Closas, var. nov

Fig. 7A-D

1993 Clypeator corrugatus - Avram et al., p. 291, Fig. 12e

Derivation of name. From the Latin bractea (noun) meaning bract cell and latus (adj.) meaning large, referring to the large size of these bract cells.

Holotype. Number LPB_IV_CH 165. Collection number of the Laboratory of Palaeontology of Bucharest (Fig. 6B).

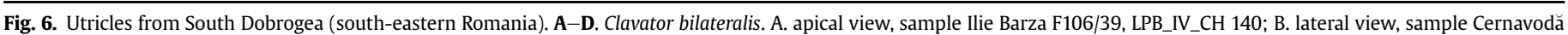

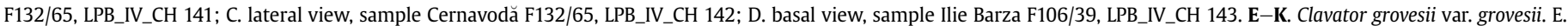

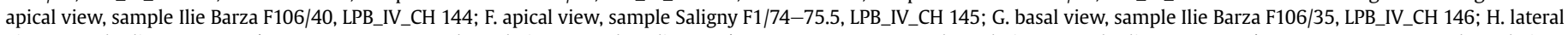

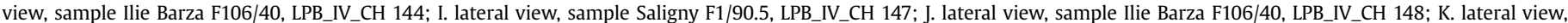

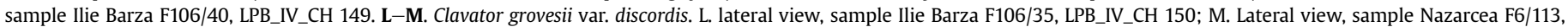

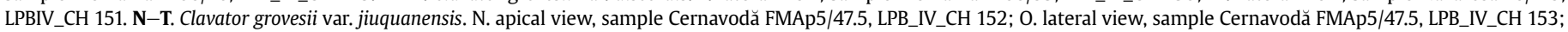

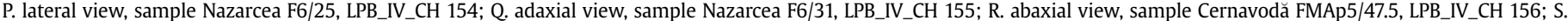

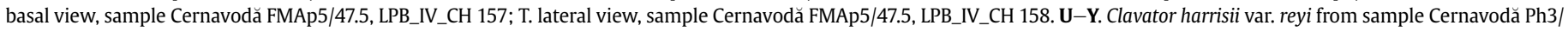
57.6-56.8. U. apical view, LPB_IV_CH 159; V. lateral view, LPB_IV_CH 160; W. lateral view, LPB_IV_CH 161; X. lateral view, LPB_IV_CH 162 ; Y. basal view, LPB_IV_CH 163. 

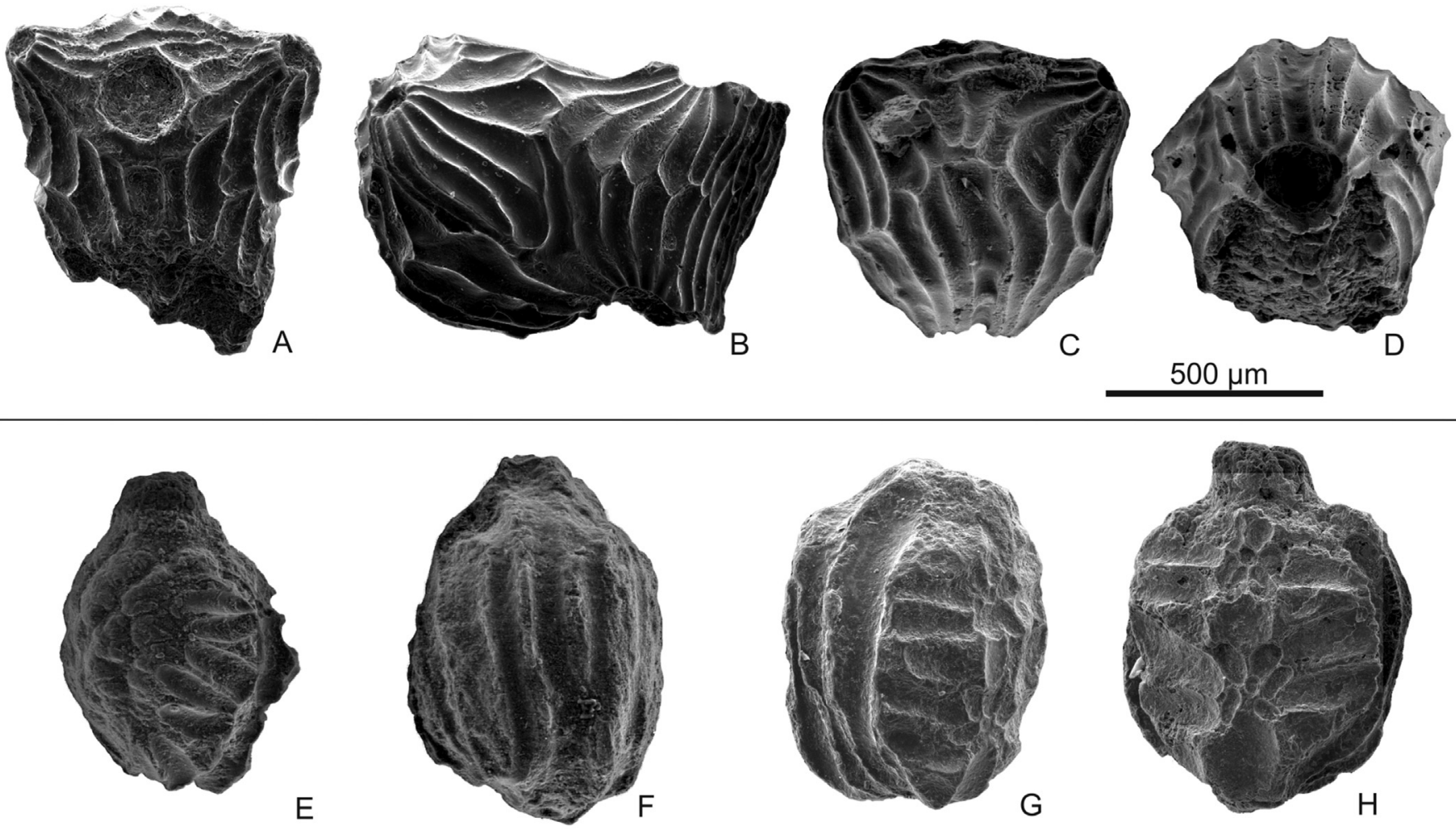

$500 \mu \mathrm{m}$

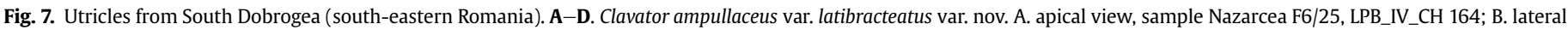

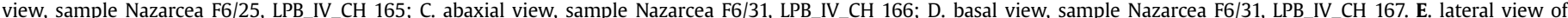

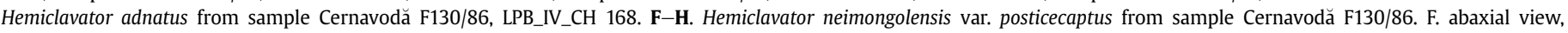
LPB_IV_CH 169; G. lateral view, LPB_IV_CH 170; H. adaxial view, LPB_IV_CH 171.

Paratypes. Numbers LPB_IV_CH 164, LPB_IV_CH 166, LPB_IV_CH 167. Collection number of the Laboratory of Palaeontology of Bucharest (Fig. 6A, C, and D).

Type locality. Nazarcea, sample from the borehole F6, $25 \mathrm{~m}$ deep. Type stratum. Marl interval within the Gherghina Formation, located $25 \mathrm{~m}$ deep in Nazarcea's borehole F6. This species also occurs at $31 \mathrm{~m}$ deep in the same borehole (Table 1).

Material. A reduced number of well-preserved utricles from two samples in Nazarcea (Table 1). Three utricles from sample Nazarcea F6/31 were measured for the description.

Diagnosis. Utricle bilaterally symmetrical, formed by the adaxial phylloid, two lateral internal bract cells and an abaxial bract cell. The two internal lateral bract cells emerge close to the apical pore, each emitting fourteen bract cells that form a symmetric shield, covering the upper half of the utricle. Eight large basal cells emerge close to the basal pore, completely covering the lower half of the utricle.

Description. Gyrogonites are clavatoroid. Utricles are large, 717-822 $\mu \mathrm{m}$ high $(769 \mu \mathrm{m}$ mean $)$ and $740-865 \mu \mathrm{m}$ wide $(802 \mu \mathrm{m}$ mean), subglobular in shape with an internal nodular layer, non-visible from the outside, and a well-developed structured external layer. The external layer shows the characteristic bilateral symmetry of the Clavatoroidae and contains a well-calcified portion of the phylloid in an adaxial position, the impression of an abaxial bract cell opposite the phylloid (Fig. 7C), and two long lateral bract cells that are not visible from the outside and emerge near the apical part of the utricle surface, forming a small pore (Fig. 7A). Each of the lateral bract cells bears, at its tip, 14 elongated radial cells forming an almost symmetrical conical shield that covers the upper half of the utricle (Fig. 7B). In addition, up to eight elongated basal cells are attached to the basal pore at each side of the utricle, completely covering its lower half (Fig. 7D). The cells of the lateral shields are in contact with the basal cells in a zigzag line near the utricle's equator. A similar indentation occurs between the cells of the two lateral shields. The apical pore is rounded and very large, about 200 $\mu \mathrm{m}$ in diameter (Fig. 7A).

Remarks. The new variety shares, in common with C. ampullaceus var. ampullaceus, the nominal variety from Mount Lebanon (Lebanon and Israel) described by Grambast and Lorch (1968), (1) the occurrence of two long internal lateral bract cells that emerge near the apex and (2) the occurrence of many basal cells. However, the new variety displays only eight basal cells, of large diameter, in contrast to the fourteen thin cells in the nominal variety. There are 14 lateral shield cells in the Romanian variety, while in the nominal variety it ranges from 14 to 18 . Moreover, the nominal variety shows very asymmetric lateral shields, with the lower half being much larger than the upper half, while in the new variety the shields are almost symmetrical. Many of the lower shield cells of the nominal variety are long enough to reach the utricle base and are deeply interdigitated with the basal cells, while in the new variety the shield cells do not trespass over the utricle equator and are barely interdigitated with the basal cells. Finally, South Dobrogean utricles from $C$. ampullaceus are $\sim 150 \mu \mathrm{m}$ smaller than the utricles of the Middle East. However, morphometric parameters are very variable in clavatoraceans and they are not used as a diagnostic character for distinguishing taxa.

Distribution. This taxon has already been illustrated in South Dobrogea by Avram et al. (1993), who erroneously named it Clavator corrugatus. This species has been found in estuarine-related 
facies in the Mount Lebanon range (Lebanon and Israel) by Grambast and Lorch (1968) and Granier et al. (2015). Luger and Schudack (2001) documented this species in non-marine rocks from the Al Mado mountain chain (central northern Somalia). The present report represents the first occurrence of Clavator ampullaceus, both outside of the Gondwanian realm and in the northeastern islands of the Cretaceous Tethyan Archipelago.

Age. Late Barremian to early Aptian, due to its occurrence in South Dobrogea with the species $C$. grovesii var. jiuquanensis, which agrees with the age of its nominal variety from the Middle East (Granier et al., 2015).

\section{Genus Hemiclavator Wang et Lu, 1982}

Hemiclavator adnatus (Martín-Closas et Grambast-Fessard, 1986) Schudack, 1989

Fig. 7E

Material. A reduced number of utricles from six samples in the localities of Cernavodă and Fetesti Baltă (Table 1). Eight utricles from sample Cernavodă F130/86 were measured.

Description. Gyrogonites are clavatoroid. Utricles are ellipsoidal and bottle-shaped, measuring 560-720 $\mu \mathrm{m}$ high (mean $601 \mu \mathrm{m}$ ) and 376-453 $\mu \mathrm{m}$ wide (mean $436 \mu \mathrm{m}$ ), with an ISI of 150 . The utricle is organised in an internal nodular layer covered only in the adaxial area by an external structured layer. This layer is composed of the phylloid impression, bearing one or two fans of six short lancetshaped cells, three at each side of the phylloid and attached to one of its nodes (Fig. 7E).

Distribution. This species is widely represented in the Iberian Peninsula and it was considered an endemic species by MartínClosas (2000). The occurrence of this taxon in South Dobrogea indicates a wider palaeogeographic distribution in the Cretaceous Tethyan Archipelago.

Age. In the Iberian Peninsula this species is Valanginian to early Barremian in age (Martín-Closas, 2000). However, in one of the studied samples, this species is associated with Globator maillardii var. nurrensis, suggesting that its time span in Romania began earlier, in the late Berriasian.

Hemiclavator neimongolensis Wang et Lu, 1982

Hemiclavator neimongolensis var. posticecaptus (Martín-Closas et Grambast-Fessard, 1986) Martín-Closas, 1996
Fig. 7F-H

Material. It occurs in four samples from Poarta Albă, Cernavodă, and Fetesti Baltă (Table 1). Ten utricles were measured from sample Cernavodă F130/86.

Description. Gyrogonites are clavatoroid. Utricles are bottle-shaped, measuring 559-740 $\mu \mathrm{m}$ high (mean $622 \mu \mathrm{m}$ ) and 408-493 $\mu \mathrm{m}$ wide (mean $471 \mu \mathrm{m}$ ), formed by an internal nodular layer and an external structured layer. The adaxial part of the external layer is very similar to that described for $H$. adnatus. However, the impressions of the phylloid nodes appear to bear a composite system of bracts, with a rosette of five small rounded cells subtending the larger lancet cells (Fig. 7H). In the anterior or abaxial part of the utricle, between four and nine long, filiform cells can be distinguished (Fig. 7F and G). They split radially from the utricle's base and may reach its apical region.

Distribution. H. neimongolensis var. posticecaptus is a well-known species occurring mainly in western European basins such as in the Iberian Chain (Spain), Chartreuse (France), and perhaps in Aït Attab, Morocco (Mojon et al., 2009). This taxon has already been mentioned by Avram et al. (1993) in Romania (South Dobrogea), however, neither the taxonomic description nor the illustrations provided by these authors were clear enough to support this taxonomic attribution. The present work confirms the occurrence of this species in the eastern part of the Cretaceous Tethyan Archipelago.

Age. In the Iberian Peninsula this species is Valanginian to early Barremian in age (Martín-Closas, 2000). However, in one of the studied samples this species occurs associated with G. maillardii var. nurrensis, suggesting that its time span in Romania began earlier, in the late Berriasian.

\section{Discussion}

\subsection{Biostratigraphy}

The charophyte assemblages from the two lithological units studied, the Zăvoaia Member of the Amara Formation, and the Gherghina Formation, are clearly distinguished in terms of taxonomy and biostratigraphy:

\begin{tabular}{|c|c|c|c|c|}
\hline 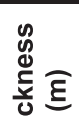 & \multicolumn{2}{|c|}{ Lithostratigraphic units } & $\begin{array}{c}\text { Previous studies } \\
\text { Ostracod biozonation and relative ages }\end{array}$ & $\begin{array}{c}\text { This study } \\
\text { European charophyte biozonation and relative } \\
\text { ages }\end{array}$ \\
\hline & \multicolumn{2}{|c|}{ Dragastan et al. (1998) } & Stoica (2007) and Antoniade (2016) after Horne (1995) & Riveline et al. (1996) and Martín-Closas et al. (2009) \\
\hline 온 & \multicolumn{2}{|c|}{ Gherghina Fm } & $\begin{array}{c}\text { Theriosynoecum fittoni } \\
\text { Barremian }\end{array}$ & $\begin{array}{c}\text { Ascidiella cruciata-Pseudoglobator paucibracteatus } \\
\text { late Barremian-early Aptian } \\
\sim 117-122 \mathrm{My}\end{array}$ \\
\hline 守 & \multicolumn{2}{|c|}{ Cernavodâ Fm } & \multicolumn{2}{|c|}{ Marine deposits } \\
\hline $\begin{array}{l}8 \\
0 \\
1 \\
1 \\
0\end{array}$ & Amara Fm & $\begin{array}{l}\text { Variegated } \\
\text { Zăvoaia Mbr }\end{array}$ & $\begin{array}{l}\text { Cypridea granulosa } \\
\text { middle Berriasian }\end{array}$ & $\begin{array}{l}\text { Globator maillardii nurrensis } \\
\text { Upper part of the middle Berriasian } \\
\sim 138-140 \mathrm{My}\end{array}$ \\
\hline
\end{tabular}

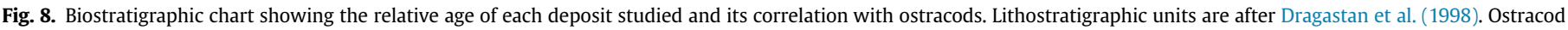

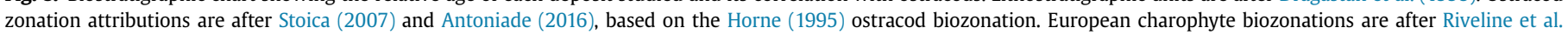
(1996), Riveline in Hardenbol et al. (1998), and Martín-Closas et al. (2009). Ages are according to Ogg et al. (2016). 
a) Zăvoaia Member (Amara Formation): The charophyte assemblage from the upper variegated part of this unit, in the boreholes of Saligny, Dunărea, Nazarcea, and Ilie Barza, is dominated by Nodosoclavator bradleyi, Clavator bilateralis, C. grovesii var. grovesii, C. grovesii var. discordis, Feistiella bijuescensis, and aff. Mesochara harrisii. Other less abundant species include Atopochara trivolvis var. micrandra, and Mesochara dobrogeica sp. nov. This assemblage can be attributed either to the Berriasian s.l. or to the middle to late Berriasian (in the samples with A. trivolvis var. micrandra associated with $C$. grovesii var. grovesii), which is compatible with the age given by a previous biostratigraphic study performed in the same unit and based on non-marine ostracods (Stoica, 2007). This author correlated the ostracod assemblage of the Zăvoaia Member with the first two Cypridea zones of the English Purbeck, i.e., the Cypridea dunkeri Zone and part of the Сypridea granulosa Zone of Anderson (1985). Moreover, the ostracod assemblage was also correlated with the lower part of the Theriosynocum forbersi Zone, and the Cypridea dunkeri and Cypridea granulosa subzones of Horne (1995). In addition to the two index species, Stoica (2007) identified other Cypridea, i.e., C. setina Anderson, 1939, C. tumescens Anderson, 1939, C. tumescens praecursor Oertli, 1963, Cypridea sp.1, Cypridea sp.2, and Cypridea sp.3. These species occur in the Zăvoaia Member associated with other Purbeckian ostracods belonging to the genera Rhinocypris, Damonella, Darwinula, Klieana, Fabanella, Mantelliana, Mongolianella, Paracypris, Pontocyprella, Scabriculocypris, Stenestroemia, Stenocypris, Theriosynoecum, Timiriasevia, Virgatocypris, and Wolburgia. Based on this rich ostracod assemblage, Stoica (2007) provided a relative age of middle Berriasian for the upper variegated part of the Zăvoaia Member (Fig. 8). However, there is a biostratigraphic conflict between charophytes and ostracods in some samples from the localities Cernavodă, Fetesti Baltă, and Poarta Albă, which provided a high number of well-preserved utricles of the species Hemiclavator adnatus and $H$. neimongolensis var. posticecaptus. Both species are well known in uppermost Berriasian to lowermost Barremian sedimentary sequences in western European basins and are common species of the European charophyte biozones Globator maillardii steinhauseri and Atopochara trivolvis var. triquetra

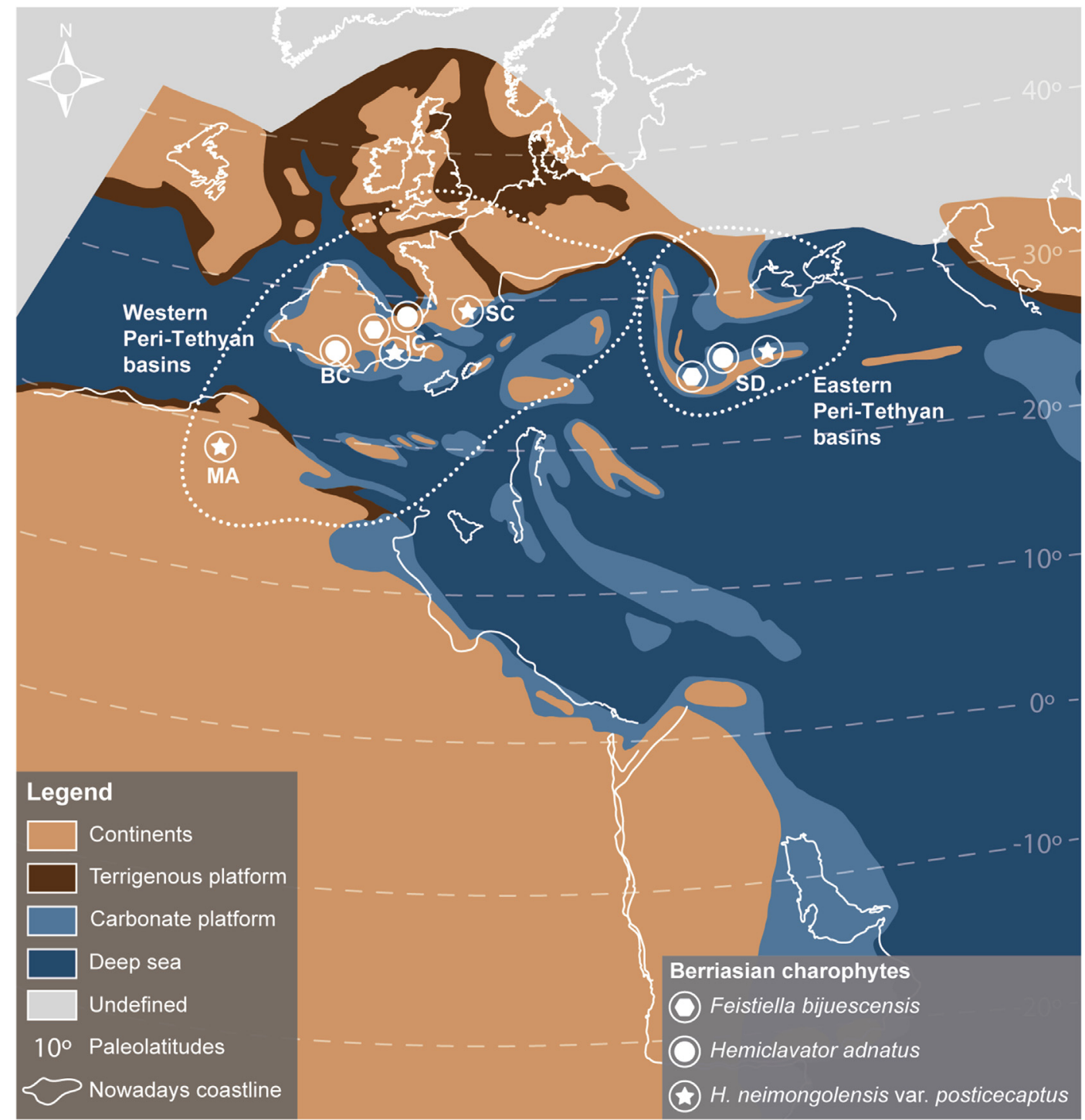

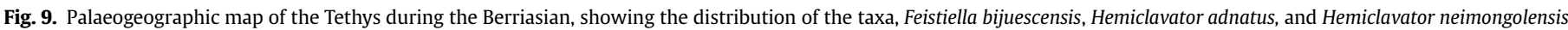

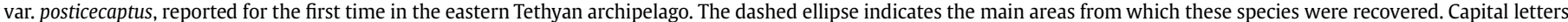

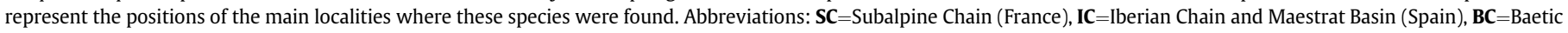
Chain (Spain), MA = Moroccan Atlas (Morocco), and SD=South Dobrogea (south-eastern Romania). Palaeogeographic map modified from Dercourt et al. (1993). 


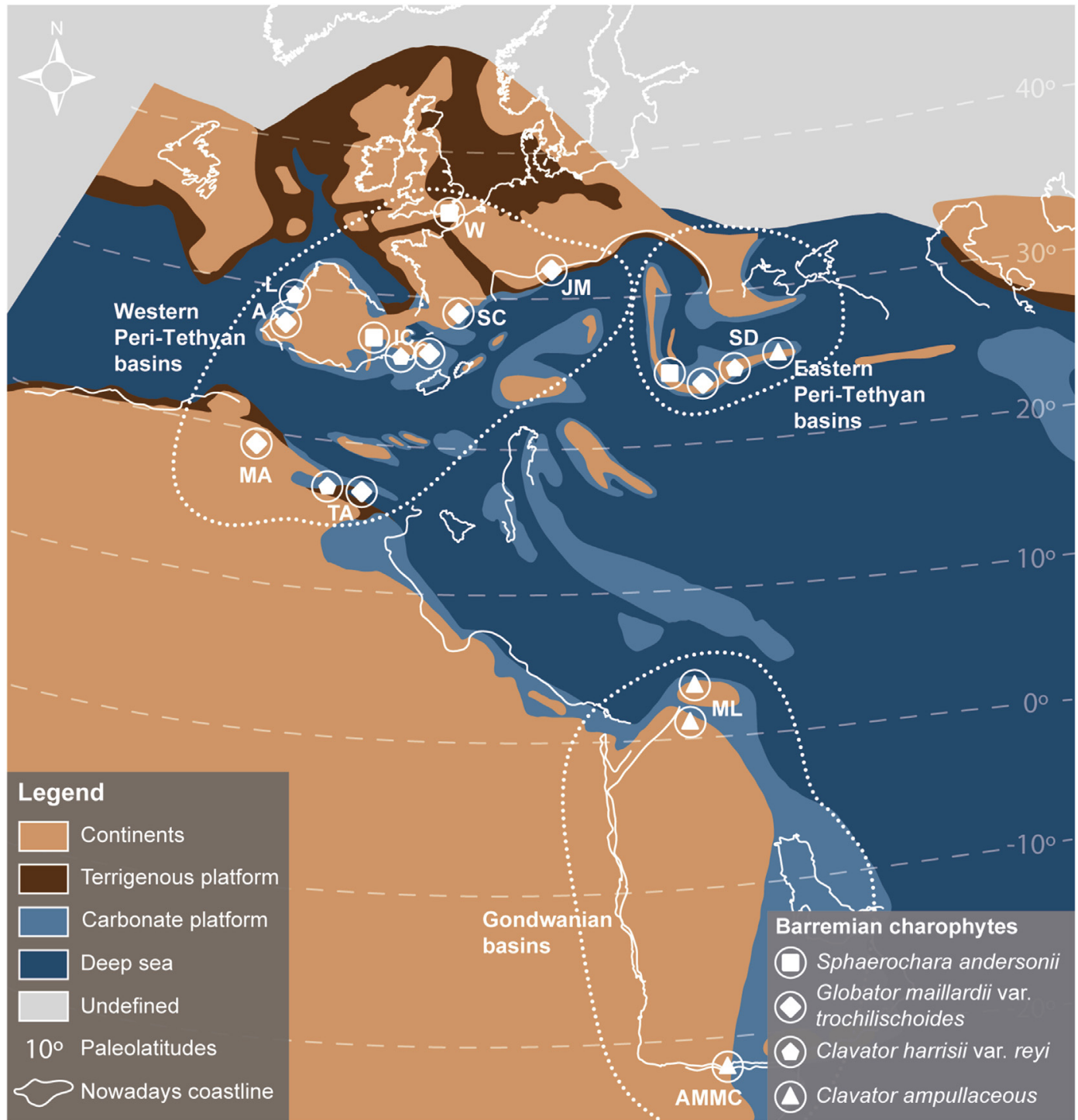

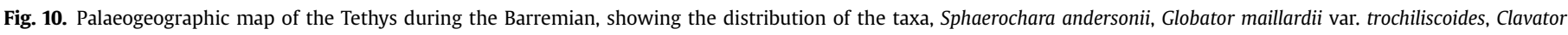

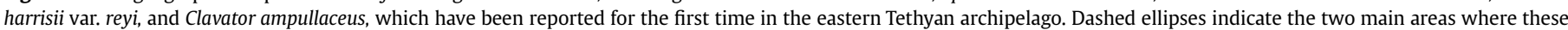

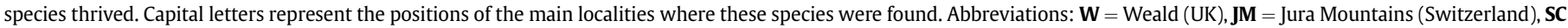

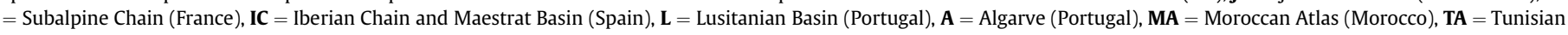

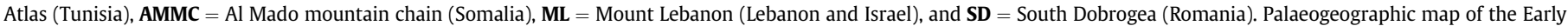
Cretaceous, modified from Dercourt et al. (1993).

(Riveline et al., 1996). Additionally, one sample in Cernavodă POD provided utricles of Globator maillardii var. nurrensis, which is considered the index species of the homonymous European charophyte biozone Globator maillardii nurrensis, that indicates late Berriasian age (Riveline et al., 1996). Ostracod biostratigraphic data and the occurrence of $H$. adnatus and $H$. neimongolensis var. posticecaptus associated with $G$. maillardii var. nurrensis in one of the samples from Cernavodă suggest that the three species may be older in Romania than in western Europe. Alternatively, given the correlation of $G$. maillardii var. nurrensis with the ammonite biozonation in the Swiss Jura (Détraz and Mojon, 1989), the Zăvoaia Member at Cernavodă may have reached the late Berriasian.

b) Gherghina Formation: The charophyte assemblage recovered from this unit is dominated by the species Atopochara trivolvis var. triquetra and Clavator grovesii var. jiuquanensis. Less abundant species include Sphaerochara andersonii, aff. Mesochara harrisii, and Clavator ampullaceus var. latibracteatus var. nov., which occur in the drilling core F6 in Nazarcea, and Globator maillardii var. trochiliscoides, Globator maillardii var. biutricularis, and Clavator harrisii var. reyi in samples from Cernavodă (drilling boreholes FMAp5 and Ph3). This assemblage can be attributed to the European charophyte biozone, Ascidiella cruciata-Pseudoglobator paucibracteatus, of Martín-Closas et al. (2009), indicating that the relative age of the Gherghina Formation is late Barremian to early Aptian (Fig. 8). This age attribution is compatible with the relative ages previously assigned to the Gherghina Formation. According to Avram et al. (1993), this unit is Aptian in age, based on its stratigraphic position between the lower Aptian Ramadan Formation and the Albian Cochirleni Formation, and its palynomorph, ostracod and charophyte assemblages. The ostracod assemblage of the Gherghina Formation has recently been studied in detail by Antoniade (2016), who described four freshwater species, Theriosynoecum fittoni Mantell, 1844, Cypridea sp. 1. (possibly referring to Cypridea recta recta), Cypridea sp. 2 (possibly referring to Cypridea fasciata), and Cypridea sp. 3. The occurrence of $T$. fittoni is significant from the biostratigraphic viewpoint since it represents a 
characteristic taxon of the Weald Clay (England) associated with the Cypridea valdensis Zone (the last Wealdian ostracod zone of Anderson (1985)) which is Barremian in age. Horne (1995) also defined a homonymous biozone (Theriosynoecum fittoni Zone) for the Weald Clay (Wealden Group) of England. According to this author, the Theriosynoecum fittoni Zone displays a wide biostratigraphic range including the Hauterivian and the Barremian. However, the extension of the biostratigraphic range of this freshwater species in younger deposits (e.g., Aptian) cannot be excluded since in its type locality (Weald, England) fully marine facies cover the last occurrences of this species. Hence, younger biostratigraphic ranges may be detected elsewhere, such as in South Dobrogea.

\subsection{Palaeobiogeography}

The charophyte assemblage obtained from surface and subsurface sedimentary sequences in South Dobrogea (south-eastern Romania) sheds new light on the biogeographic distribution of charophytes in the Early Cretaceous Tethyan Archipelago and particularly in comparison with other palaeoislands of this palaeogeographic domain, i.e., the western area (nowadays western Europe and North Africa) and the southern margin of the Tethys (nowadays the Middle East and eastern Africa) (Figs 9 and 10).

The flora described in the Berriasian Zăvoaia Member comprises a total of 12 taxa, some of them already reported in South Dobrogea or nearby basins. This Berriasian assemblage displays a clear affinity with the flora of the western part of the Cretaceous Tethyan archipelago. The number of common species is even higher than previously thought, with the three additional species (F. bijuescensis, H. adnatus, and H. neimongolensis var. posticecaptus) now reported both in South Dobrogea (south-eastern Romania) and the western European region (Fig. 9). Very significantly, this is the first description in Europe of $C$. bilateralis, previously considered as endemic to North America. Although this species has previously been mentioned under the name of a younger synonym, Clavator minutus, in biostratigraphic studies from Pre-Dobrogea and South Dobrogea (Shaikin, 1976 and Avram et al., 1993, respectively), insufficient description and understanding of this species in its type locality in the United States, meant that these reports remained largely ignored. Recently, C. bilateralis has been re-defined and illustrated in the Western Interior Basin of North America by Martín-Closas et al. (2013), which allows confirmation of its occurrence in almost all samples studied within the Zăvoaia Member. This result points to an intercontinental distribution of C. bilateralis during the Berriasian, and to it thriving in distant basins at similar palaeolatitudes. Another species from the same studied assemblage, $C$. grovesii var. grovesii, had an even broader range during the Berriasian, from North America and Europe to China (Martín-Closas, 2015 and references therein). The absence of C. bilateralis in the Berriasian of western Europe is difficult to interpret but may be related to as yet unknown palaeoecological restrictions of this species.

The charophyte assemblage described within the Gherghina Formation is composed of nine species, four of which had previously been considered endemic to the western Barremian/Aptian Tethyan archipelago. These species are S. andersonii, G. maillardii var. trochiliscoides, G. maillardii var. biutricularis, and C. harrisii var. reyi (Fig. 10). In addition, the occurrence of $C$. ampullaceus in South Dobrogea is noteworthy (Fig. 10). This taxon was previously known exclusively from the Middle East (Mount Lebanon), by Grambast and Lorch (1968), and NE Africa (Al Mado mountain chain in northern Somalia), by Luger and Schudack (2001). Palaeogeographic reconstructions of the Mesogea during the Early Cretaceous place the regions of Lebanon and Somalia at much lower latitudes than at present, i.e., near the equator, while the northern islands of the Cretaceous Tethyan Archipelago were located at between $20^{\circ}$ and $30^{\circ}$ north latitude (Dercourt et al., 1993). Thus, latitude was apparently not a biogeographic barrier for C. ampullaceus. Biome reconstruction of the Mesogean Early Cretaceous by Scotese (2003) indicates that tropical conditions prevailed in the south-eastern Tethys (e.g., Lebanon and Somalia) and more subtropical but still hot and humid conditions in the north-eastern part of the Cretaceous Tethyan Archipelago (e.g., South Dobrogea), while the climate was drier in the western palaeoislands of the same archipelago (e.g., Iberia). This may explain why $C$. bilateralis does not occur in the Berriasian of western Europe.

\section{Conclusions}

Twenty charophyte species are described and illustrated from two Lower Cretaceous surface and subsurface continental units (the Zăvoaia Member of the Amara Formation and the Gherghina Formation) belonging to the South Dobrogea Basin (south-eastern Romania). This study revisits and clarifies the taxonomy of Lower Cretaceous Romanian charophytes provided by the pioneering studies of Neagu and Georgescu-Donos (1973), and Avram et al. (1993), with samples from the same basin, and provides new biostratigraphic and biogeographic data. Two charophyte assemblages are clearly distinguished in each of the two lithological units.

The assemblage found in the variegated interval of the Zăvoaia Member is composed of 12 taxa, including Feistiella bijuescensis, Atopochara trivolvis var. micrandra, aff. Mesochara harrisii, Nodosoclavator bradleyi, Clavator bilateralis, Clavator grovesii var. grovesii, and Clavator grovesii var. discordis, which can be attributed to the middle to late Berriasian. However, in some samples, the occurrence of Globator maillardii var. nurrensis, which is common in the upper Berriasian of western Europe and is well correlated with the ammonite biozonation, suggests that this unit may have reached younger ages than previously thought. A new species, Mesochara dobrogeica sp. nov., is described within the Zăvoaia Member (Amara Formation). Furthermore, the presence of Hemiclavator adnatus and Hemiclavator neimongolensis var. posticecaptus, associated with Globator maillardii var. nurrensis and with middle Berriasian ostracods suggests that these charophytes are older in Romania than in western Europe, where they occur first in the Valanginian. On the other hand, the charophyte assemblage recovered from the Gherghina Formation is composed of eight taxa dominated by Atopochara trivolvis var. triquetra and Clavator grovesii var. jiuquanensis. These species can be attributed to the Ascidiella cruciataPseudoglobator paucibracteatus European charophyte biozone (late Barremian to early Aptian). The suggested relative age of both continental rock units, based on charophyte assemblages, is only in partial agreement with the ages provided by previous biostratigraphic works performed in the area, based on ostracods.

This study gives new insights into the palaeogeographic distribution of Lower Cretaceous charophytes in the Cretaceous Tethyan Archipelago. Both the charophyte assemblages studied display strong affinities with the flora from the western part of the archipelago. However, the occurrence of the thus far exclusively North American taxon, C. bilateralis, in Romania suggests that this species had an intercontinental distribution despite not having been recorded in western Europe, which is probably due to palaeoecological factors. In addition, the occurrence of the north Gondwanian $C$. ampullaceus in Romania has been attributed to palaeoclimatic controls. Moreover, a new variety of this species, C. ampullaceus var. latibracteatus var. nov. is described herein. These new findings enhance the biostratigraphic value of these species for intercontinental biostratigraphic correlation. 


\section{Acknowledgements}

This is a contribution to the projects, BIOGEOEVENTS (CGL 201569805-P) of the Spanish Ministry of Economy and Competitiveness ERDF (EU) and the European Regional Development Fund (ERDF), and 2017SGR-824 of AGAUR (Catalan Research Agency). This study was co-funded by the Research Leave Grant 2020 provided by the American University of Beirut (AUB). This research was part of the international exchange of Dr. Vicente during her postdoctoral fellowship (DGAPA-UNAM). The research of JP-C was also supported by the predoctoral grant BES-2016-076469 from the Spanish Ministry of Economy and Competitiveness. We thank Mr. David Artiaga (Scientific and Technological Centres of the University of Barcelona, CCiT-UB) for his help and technical support during the SEM sessions. We are very grateful to the editorin-chief Dr. Eduardo Koutsoukos, and to Dr. Ioan I. Bucur and Dr. Li Sha for their constructive comments and suggestions during the peer-review process. The English text was corrected by Dr. Christopher Evans (Fundació Bosch i Gimpera, University of Barcelona).

\section{References}

Agardh, C.A., 1824. Systema Algarum. Lundae Literis Berlingianis, Lund, pp. 1-312. Anderson, F.W., 1939. Wealden and Purbeck Ostracoda. Annals Magazine Natural History 3, 290-310. London.

Anderson, F.W., 1985. Ostracod faunas in the Purbeck and Wealden of England. Journal of Micropalaeontology 4 (2), 1-68.

Antoniade, G.-C., 2016. Studiul lito-biostratigrafic al depozitelor de vârstă Cretacic inferior din zona Cernavodă, Dobrogea de Sud. Unpublished PhD Thesis. Bucharest University, Bucharest, p. 225.

Avram, E., Drăgănescu, A., Szass, L., Neagu, Th., 1988. Stratigraphy of the outcropping Cretaceous deposits in Southern Dobrogea (SE Romania). Mémoires, Institute Géologie et Géophysics 33, 5-43.

Avram, E., Szasz, L., Antonescu, E., Baltreș, A., Iva, M., Neagu, Th., Rădan, S., Tomescu, C., 1993. Cretaceous terrestrial and shallow marine deposits in northern South Dobrogea (SE Rumania). Cretaceous Research 14, 265-305.

Avram, E., Costea, I., Dragastan, O., Muţiu, R., Neagu, Th., Şindilar, V., Vinogradov, C., 1995. Distribution of the Middle-Upper Jurassic Cretaceous facies in the Romanian eastern part of the Moesian Platform. Revue Roumaine de Géologie 39-40, 3-33.

Băncilă, I., 1973. The presence of the Purbeckian-Wealdian gypsiferous formation in the Fetesti-Constanta region. "Asupra prezenței unei formațiuni gipsifere Purbekian-Wealdiene în regiunea Fetesti - Constanta; On the presence of Purbeckian-Wealdian Formation in the Fetesti-Constanta region". Studii si cercetari de Geologie, Geofizica si Geografie, Serie de Geologia 18/1, 115-125.

Dercourt, J., Ricou, L.E., Vrielynck, B., 1993. Atlas Tethys, Palaeoenvironmental Maps. Gauthier-Villars, p. 260.

Détraz, H., Mojon, P.O., 1989. Évolution paléogéographique de la marge jurassienne de la Téthys du Tithonique -Portlandien au Valanginien: Correlation biostratigraphique et séquentielle des facies continentaux. Eclogae Geologicae Helvetiae 82 (1), 37-112.

Dragastan, O., 1985. Upper Jurassic and Lower Cretaceous Formations and Facies in the Eastern area of the Moesian Platform (South Dobrogea included). Analele Universitatii București, Geologie 34, 77-85.

Dragastan, O., Neagu, Th., Barbulescu, A., Pana, I., 1998. Jurasicul si Cretacicul din Dobrogea Centrala si de Sud (Paleontologie si Stratigrafie). Cluj-Napoca Supergraph Tipo, p. 249 (in Romanian).

Dragastan, O.N., Antoniade, G.-C., Stoica, M., 2014. Biostratigraphy and zonation of the Lower Cretaceous carbonate succession from Cernavodă -lock section, South Dobrogea, eastern part of the Moesian Platform (Romania). Carpathian Journal of Earth and Environmental Sciences 9 (1), 231-260.

Feist, M., Cubaynes, R., 1984. Découverte de Charophytes dans le Lias du Sud de la France. Implications paléoécologiques et phylogénétiques. Comptes-rendus de l'Académie des Sciences de Paris 299 (2), 593-596.

Feist, M., Lake, R.D., Wood, C.J., 1995. Charophyte biostratigraphy of the Purbeck and Wealden of Southern England. Palaeontology 38, 407-442.

Feist, M., Grambast-Fessard, N., Guerlesquin, M., Karol, K., Lu, H.N., Mc-Court, R.M., Wang, Q.F., Zhang, S.Z., 2005. Treatise on Invertebrate Paleontology. Part B, Protoctista 1. Charophyta, vol. 1. The Geological Society of America, Lawrence, Kansas, p. 170.

Grambast, L., 1962. Classification de l'embranchement des charophytes. Naturalia Monspeliensia, Série Botanique 14, 63-86.

Grambast, L., 1965. État des connaissances acquises sur les charophytes du Crétacé inférieur. Mémoires du Bureau des Recherches Géologiques et Minières 34, $577-582$.
Grambast, L., 1966. Un nouveau type structural chez les Clavatoracées, son intérêt phylogénetique et stratigraphique. Comptes Rendus de l'Académie des Sciences, de Paris 262, 1929-1932.

Grambast, L., 1967. La série évolutive Perimneste-Atopochara (Charophytes). Comptes Rendus de l'Académie des Sciences de Paris 264, 581-584.

Grambast, L., 1968. Evolution of the utricle in the charophyta genera Perimneste Harris and Atopochara Peck. Journal of the Linnean Society (Botany) 61, 5-11.

Grambast, L., 1969. La symétrie de l'utricule chez les Clavatoracées et sa signification phylogénétique. Comptes Rendus Comptes Rendus de l'Académie des Scienes de Paris 269, 878-881.

Grambast, L., 1970. Origine et évolution des Clypeator (Charophytes). Comptes Rendus de l'Académie des Sciences de Paris 271, 1964-1967.

Grambast, L., Lorch, J., 1968. Une flore de Charophytes de Crétacé inférieur du Proche Orient. Naturalia Monspeliensis 19, 47-56.

Grambast-Fessard, N., 1980. Quelques espèces de Cypeator Grambast (Clavatoraceae) et les charophytes associées du Crétacé inférieur du Portugal. Revue de Micropaléontologie 23, 37-47.

Granier, B., Azar, D., Maksoud, S., Geze, R., Habchi, R., 2015. New fossiliferous sites with Barremian Charophyta in the "Grès du Liban" auct. (Lebanon), with a critical perspective regarding the nature of Munieria Deecke, 1883. Carnets de Geologie 15, 199-229.

Hardenbol, J., Thierry, J., Martin, B.F., Jacquin, T., Graciansky, P.C., Vail, P.R., 1998. Mesozoic and Cenozoic squence chronostratigraphic framework of European basins. Society for Sedimentary Geology (SEPM), Tulsa, Oklahoma. Special Publication 60.

Harris, T.M., 1939. British Purbeck Charophyta. British Museum (Natural History), p. 83.

Heer, O., 1865. Die Urwelt der Schweiz. Impr. Schulthess, Zrich, p. 800.

Horn af Rantzien, H., 1959. Morphological types and organ-genera of Tertiary charophyte fructifications. Stockholm Contributions in Geology IV (2), 45-197.

Horne, D.J., 1995. A revised ostracod biostratigraphy for the Purbeck-Wealden of England. Cretaceous Research 16, 639-663.

Huang, R., 1985. Cretaceous and early Tertiary charophytes from Sichuan. Acta Micropaleontologica Sinica 2 (1), 77-89 in Chinese.

Ionesi, L., 1994. Geology of the platform units and North Dobrogea orogeny. Tehnică, Bucharest, Romania, p. 280 in Romanian.

Luger, P., Schudack, M., 2001. On Early Cretaceous (earliest Aptian) freshwater Charophyta and Ostracoda from Northern Somalia. Neues Jahrbuch für Geologie und Paläontologie Abhandlungen 220 (2), 245-266.

Mädler, K., 1952. Charophyten aus dem Nordwestdeutschen Kimmeridge. Geologisches Jahrbuch 67, 1-46.

Mädler, K., 1955. Zur Taxinomie der tertiaren Charophyten. Geologisches Jahrbuch $70,265-328$.

Malz, H., 1969. Jura/Kreide-Grenzschichten in SE-Europa. Natur und Museum 99 (2), 56-64.

Mantell, G.A., 1844. Medals of Creation: or first lessons in geology and in the study of organic remains, vol. 2. Henry G. Bohn, London, p. 1016.

Martín-Closas, C., 1996. A phylogenetic system of Clavatoraceae (Charophyta). Review of Palaeobotany and Palynology 94, 259-293.

Martín-Closas, C., 2000. Els caròfits del Juràssic superior i el Cretaci inferior de la Península Ibèrica. Premi Josep R. Bataller. Institut dEstudis Catalans, p. 304.

Martín-Closas, C., 2015. Cosmopolitanism in Norhern Hemisphere Cretaceous Charophyta (Clavatoroidae). Palaeogeography, Palaeoclimatology, Palaeoecology 438, 9-23.

Martín-Closas, C., Grambast-Fessard, N., 1986. Les charophytes du Crétacé inférieur de la région du Maestrat (Chaîne Ibérique, Catalanides, Espagne). Paléobiologie Continentale 15, 1-66.

Martín-Closas, C., Schudack, M.E., 1991. Phylogenetic analysis and systematisation of post-palaeozoic charophytes. Revue de la Société Botanique de France 138, 53-71.

Martín-Closas, C., Wang, Q., 2008. Historical biogeography of the lineage Atopochara trivolvis PECK 1941 (Cretaceous Charophyta). Palaeogeography, Palaeoclimatology, Palaeoecology 260, 435-451.

Martín-Closas, C., Clavel, B., Charollais, J., Conrad, M.A., 2009. Charophytes from the Barremian-lower Aptian of the Northern Subalpine Chains and Jura Mountains, France: correlation with associated marine assemblages. Cretaceous Research 30, 49-62.

Martín-Closas, C., Sames, B., Schudack, M.E., 2013. Charophytes from the Upper Berriasian of the Western Interior Basin of United States. Cretaceous Research $46,11-23$.

Martín-Closas, C., Vicente, A., Prez-Cano, J., Sanjuan, J., Bover-Arnal, T., 2018. On the earliest occurrence of Tolypella section Tolypella in the fossil record and the age of major clades in extant Characeae. Botany Letters 165, 23-33.

Maslov, V.P., 1961. Ne iavliaiutsia li Sitsidii i Khovanelly utrikulami kharophytov? [Are Sycidium and Chovanella not the utricles of charophytes?]. Doklady Akademii Nauk SSSR 138 (3), 677-680 (in Russian).

Migula, W., 1897. Die Characeen. In: Rabenhorst, L. (Ed.), Kryptogamen-Flora von Deutschland, Oesterreich und der Schweiz. E. Kummer, Leipzig, p. 772.

Mojon, P.O., 1989. Polymorphisme écophénotypique et paléoécologique des Porocharacées (charophytes) du Crétacé basal (Berriasien) du Jura francosuisse. Revue de Paléobiologie 8 (2), 505-524. 
Mojon, P.O., Haddoumi, H., Charrière, A., 2009. Nouvelles données sur les charophytes et ostracodes du Jurassique moyen-supérieur-Crétacé inférieur de l'Atlas marocain. Cahiers de Géologie (Notebooks on Geology), pp. 1-39. Mémoir 2009/03 (CG2009/M03).

Neagu, Th., Dragastan, O., 1984. Stratigrafia depozitelor Neojurasice și Eocretacice din Dobrogea de Sud. Studii si cercetari de Geologie, Geofizica si Geografie, Serie de Geologia 29, 80-87 (in Romanian).

Neagu, Th., Georgescu-Donos, M.O., 1973. Characeae Eocretacice die Dobrogea de Sud (Valea Akargea-Pestera). Studii si cercetari de Geologie, Geofizica si Geografie, Serie de Geologia 18, 171-185 in Romanian.

Neagu, Th., Pană, I., Dragastan, O., 1977. Stratigraphie de la série des calcaires eocretacées de l'aire Cernavodă-Alimanu-Ostrov. Revue Roumaine de Géologie, Géophysique et Géographie - Série de Géologie 21, 131-144.

Neagu, Th., Dragastan, O., Csiki, Z., 1997. Early Cretaceous shelf paleocommunities of Cernavodă (South Dobrogea, SE Romania). Acta Palaeontologica Romaniae 1, $28-36$.

Oertli, H.J., 1963. Ostracodes du "Purbeckien" du Bassin Parisien. Revue de linstitut Français du. Pétrole 18 (1), 5-39.

Ogg, J.G., Ogg, G.M., Gradstein, F.M., 2016. Concise Geologic Time Scale 2016. Elsevier Publications, p. 234.

Peck, R.E., 1937. Morrison charophyta from Wyoming. Journal of Paleontology 11, 83-90.

Peck, R.E., 1938. A new family of Charophyta from the Lower Cretaceous of Texas. Journal of Paleontology 12, 285-304.

Peck, R.E., 1957. North American Charophyta. Geological Survey Professional Paper 294 A, 144.

Pecorini, G., 1969. Le Clavatoraceae del Purbeckiano de Cala dİnferno nella Nurra di Alghero (Sardegna nord-occidentale). Bolletino della Società Sarda di Scienze Naturali 3 (5), 1-14.

Pérez-Cano, J., Bover-Arnal, T., Martín-Closas, C., 2020. Barremian charophytes from the Maestrat Basin (Iberian Chain). Cretaceous Research. https://doi.org/ 10.1016/j.cretres.2020.104544.

Pia, J., 1927. Charophyta. In: Hirmer, M. (Ed.), Handbuch der Paläobotanik, vol. 1. R. Oldenbourg Druck und Verlag, Munich-Berlin, pp. 88-93.

Reid, C., Groves, J., 1916. Preliminary report on the Purbeck Characeae. Proceedings of the Royal Society B 89, 252-256.

Riveline, J., Berger, J.P., Bilan W Feist, M., Martín-Closas, C., Schudack, M., SouliéMärsche, I., 1996. European Mesozoic-Cenozoic Charophyte Biozonation. Bulletin de la Société Géologique de France 167, 453-468.

Săndulescu, M., 1984. Geotectonica României. Tehn, București, p. 336.

Saporta, M. 1981. Plantes jurassiques. In: Masson, G. (Ed.) Paleontologie Francaise de Description Des Fossiles De La France. Wentworth Press, Paris, pp. 498-500.

Schudack, M.E., 1986. Zur Nomenklatur der Gattungen Porochara Mädler 1955 (syn. Musacchiella Feist and Grambast-Fessard 1984) und Feistiella n. gen. (Charophyta). Paläontologische Zeitschrift 60 (1/2), 21-27.

Schudack, M.E., 1989. Charophytenfloren aus den unterkretazischen VertebratenFundschichten bei Galve und Uña (Östpanien). Berliner geowissenschaftliche Abhandlungen A 106, 409-443.

Schudack, M.E., 1993. Die Charophyten im Oberjura und Unterkreide Westeuropas. Mit einer phylogenetischen Analyse der Gesamtgruppe. Berliner geowissenschaftliche Abhandlungen, Reihe A 8, 1-209.
Scotese, C.R., 2003. Paleomap Project. http://www.scotese.com. (Accessed March 2020).

Shaikin, I.M., 1967. Fossil Charophyta of Upper Jurassic deposits of Dniepr-Donets depression. Fossil Algae of the USSR. IZDAT Nauk SSSR 43-47 (in Russian).

Shaikin, I.M., 1976. New data on biostratigraphy of the Jurassic and Cretaceous of the Fore-Dobrogean Trough. Geologicheskiy Zhurna 36 (2), 63-72 (in Russian, English translation).

Shaikin, I., Kisielevsky, F., Vacula, L., 1992. Correlation of non-marine lower Cretaceous deposits of the South European part of the former USSR on the basis of Charophyta. Cretaceous Research 13, 331-336.

Soulié-Märsche, I., 1989. Étude comparée de gyrogonites de charophytes actuelles et fossiles et phylogénie des genres actuels. Imprimérie des Tilleuls, Millau, p. 237.

Stoica, M., 1997. Ostracods from the Purbeck of Southern Dobrogea (Romania). Acta Paleontologica Romania 1, 257-261.

Stoica, M., 2007. Ostracode Purbeckiene din Dobrogea de Sud. Ed. Ars Docendi, Bucharest, p. 218, $53 \mathrm{pl}$

Stoica, M., 2013. The Cypridea genus in Purbeckian sediments from South Dobrogea (Romania). In: 17th International Symposium on Ostracoda "Back to the future". ISSN: 0394-0063. University of Roma Tre, Rome, Italy, pp. 385-387. July 23rd-26th, 2013, abstract published in Naturalista sicil., S. XXXVII (1).

Tătărâm, N., Rado, G., Pană, I., Hanganu, E., Grigorescu, D., 1977. Dobrogea de Sud în Neozoic: biostratigrafie si paleoecologie. Studii si cercetari de Geologie, Geofizica si Geografie, Serie de Geologia 22, 27-38.

Trabelsi, K., Soussi, M., Touir, J., Houla, J., Abbes, C., Martín-Closas, C., 2016. Charophyte biostratigraphy of the non-marine Lower Cretaceous in the Centra Tunisian Atlas (North Africa): Palaeobiogeographic implications. Cretaceous Research 67, 66-83.

Vicente, A., Martín-Closas, C., 2013. Lower Cretaceous charophytes from the Serranía de Cuenca, Iberian chain: Taxonomy, biostratigraphy and palaeoecology. Cretaceous Research 40, 227-242.

Visarion, M., Săndulescu, M., Stănică, D., Veliciu, Ș., 1988. Contributions à la connaissance de la structure profonde de la plateforme Moesienne en Roumanie: Studii Tehnice si Economice. Seria Geofizică 15, 211-223 (in Romanian).

Wang, S., 1965. Mesozoic and Tertiary Charophyta from Jinquan basin of Kansu province. Acta Palaeontologica Sinica 13, 485-499.

Wang, Z., 1981. Mesozoic charophytes from Anhui and Zhejiang with its stratigraphic significance. Acta Palaeontologica Sinica 20, 311-323 (in Chinese, English abstract).

Wang, Z., Lu, H.N., 1982. Classification and evolution of Clavatoraceae with notes on its distribution in China. Bulletin Nanjing Institute of Geology and Paleontology. Academia Sinica 4, 77-104 (in Chinese).

Wang, Z., Huang, R., Wang, S., 1976. Mesozoic and Cenozoic charophytes from Yunnan. Mesozoic fossils from Yunnan 1, 65-93 (in Chinese).

\section{Appendix A. Supplementary data}

Supplementary data to this article can be found online at https://doi.org/10. 1016/j.cretres.2021.104762. 